Article

\title{
The SDGs, Ecosystem Services and Cities: A Network Analysis of Current Research Innovation for Implementing Urban Sustainability
}

\author{
Scott Hawken ${ }^{1, *(\mathbb{D})}$, Homa Rahmat ${ }^{2}$, Samad M. E. Sepasgozar ${ }^{2}{ }^{(1)}$ and Kefeng Zhang ${ }^{3}(\mathbb{D}$ \\ 1 School of Architecture and Built Environment, Faculty of Engineering, Computer and Mathematical Sciences, \\ The University of Adelaide, Adelaide 5005, Australia \\ 2 Faculty of Arts, Design \& Architecture, UNSW Sydney, Sydney 2052, Australia; \\ h.rahmat@unsw.edu.au (H.R.); Sepas@unsw.edu.au (S.M.E.S.) \\ 3 Faculty of Engineering, UNSW Sydney, Sydney 2052, Australia; kefeng.zhang@unsw.edu.au \\ * Correspondence: scott.hawken@adelaide.edu.au
}

check for updates

Citation: Hawken, S.; Rahmat, H.; Sepasgozar, S.M.E.; Zhang, K. The SDGs, Ecosystem Services and Cities: A Network Analysis of Current Research Innovation for Implementing Urban Sustainability. Sustainability 2021, 13, 14057. https://doi.org/10.3390/ su132414057

Academic Editor: Luca Salvati

Received: 28 September 2021

Accepted: 5 December 2021

Published: 20 December 2021

Publisher's Note: MDPI stays neutral with regard to jurisdictional claims in published maps and institutional affiliations.

Copyright: (c) 2021 by the authors. Licensee MDPI, Basel, Switzerland. This article is an open access article distributed under the terms and conditions of the Creative Commons Attribution (CC BY) license (https:// creativecommons.org/licenses/by/ $4.0 /)$.

\begin{abstract}
Ecosystem services are essential for cities and are key factors in achieving many of the Sustainable Development Goals (SDGs). Such services are best delivered through green infrastructure, which works in resourceful, multifunctional, synergistic, and environmentally sensitive ways to deliver ecosystem services and provide alternative cleaner pathways for the delivery of multiple urban services. It is unclear if current research supports the necessary linkages between ecosystem services, cities, and green infrastructure in order to achieve the SDGs. To answer this question, we conducted a systematic review analysing 3392 studies on the SDGs from the WoS database. The contents of 66 of those with relevance to ecosystem services and urban research were reviewed in depth. We applied network-analytic methods to map the relationships of different knowledge clusters of SDGs research (1) across time, (2) across disciplines, and (3) in relation to ecosystem services and cities. The results of our analysis show that research on the SDGs have developed stronger networks from 2010-2018, but this research has not been sustained. Further, whilst research on cities now occupies a central place in the SDGs literature, research on ecosystem services only shows tentative links to both green-infrastructure research and SDGs research. Such literature on urban green infrastructure remains peripheral to the central challenge of sustainable urban transitions. We conclude that when it comes to the SDGs, research articles typically consider urban services independently of green infrastructure. Further, it suggests that green infrastructure is not generally considered as a sustainable alternative to conventional urban infrastructures. To address this serious shortcoming, we recommend transdisciplinary approaches to link urban ecosystem and urban green infrastructure research to the 2030 global sustainability agenda.
\end{abstract}

Keywords: green infrastructure; nature-based systems; ecological infrastructure; urban infrastructure; sustainable urban transitions; bibliometric analysis; sustainable development goals; urban areas; urban design; urban planning; transdisciplinary knowledge

\section{Introduction}

The UN Sustainable Development Goals (SDGs) were introduced in September 2015 and included a goal focused on cities, SDG 11: Sustainable Cities and Communities [1]. SDG 11 acknowledges the unprecedented urbanisation taking place globally and the significance of this trend for human well-being and its critical importance to global sustainability [2]. From 2015 to 2030, over a billion people will join the world's urban population, thereby increasing the urban share of the global population to $60 \%$ [3] with Asia and Africa set to become predominantly urban by the mid-2030s and mid-2040s, respectively [4,5]. Growing cities are not well prepared to accommodate urbanising populations in a sustainable manner [6-8]. Because of insufficient and inadequate infrastructural capacity, and because 
of intensive resource use, cities are placing an unsustainable load on biodiversity and ecosystems [9-13].

The report written by the UN High-Level Panel of Eminent Persons on the Post2015 Development Agenda [14] suggests: "Cities are where the battle for sustainable development will be won or lost." However, current assessments paint a sobering account of progress towards the SDGs. The Future is Now report states that "no country is meeting basic human goals within biophysical boundaries" [15]. Around the world, cities typically fall into one of two groups: those that are within biophysical boundaries but have not met basic social standards or those that have almost met social standards but have grossly overstepped biophysical boundaries.

The observed global erosion of ecosystems and ecosystem services [16] in the face of urban development indicates that innovative, sustainable approaches to urban service delivery that enhance rather than degrade natural systems are required. Achieving sustainable patterns of living and ecologically positive economies depend upon how cities of the world re-imagine their existing infrastructure and roll out the next generation of urban infrastructure ([17]. To achieve SDG 11, sustainable cities must be constructed or retrofitted following ecological principles, green-buildings standards, and a green or ecological paradigm [18-21]. The robustness and resilience of these new urban systems are critical for them to withstand climate change, extreme weather events, and rising sea levels [22,23]. Finally, infrastructures need to be integrated as fundamental components of urban areas and their ecosystems so that economic externalities that lead to unsustainability can instead be integrated and transformed into mutually supporting systems and circular networks [24]).

This study investigated current research innovation across the three areas of ecosystem services, cities, and the SDGs. Ecosystem services can be defined as those benefits ecosystems provide to people [25]. There is a large literature on ecosystem services within specialist journals dedicated to the topic [12,26-28]. However, the contribution of ecosystem services to urban sustainability in the context of the SDGs is an emerging area that requires monitoring and review. Sustainable urbanisation involves the strategic management and development of urban ecosystem services, yet these have seldom been considered within current SDGs research on cities. Comprehensive reviews by scholars such as Wood et al. $[29,30]$ and Yang et al. [31] have mapped ecosystem services in relation to the SDGs but have not specifically focused on the massive challenge that urbanisation presents. Considering the current scale of urbanisation, there is an important need to focus on SDGs research as it relates to both ecosystems and cities. For example, case-study articles by Cumming et al. [32] and Chen et al. [33] assessed how ecosystem services can help progress towards sustainable-development goals but did not specifically address urban contexts. Here, we aimed to address this "urban" and "ecological" gap using a broad historically based bibliometric analysis tracking ecosystem research on the SDGs over several decades.

Ecosystem services are delivered by what is called "ecological infrastructure" [32]. This model of service delivery has also been called "nature-based systems" or "blue-green infrastructure" [34-36] and the more common term, "green infrastructure" (GI). Silva and Wheeler [37] define GI as "a network of natural, semi-natural and restored areas designed and managed at different spatial scales (from local to global), that encompasses all major types of ecosystems (marine, terrestrial and freshwater), and that aims to conserve biodiversity, mitigate emissions of greenhouse gases, enable societal adaptation to climate change, and deliver a wide range of other ecosystem services."

In this study, we were primarily concerned with the urban as a novel and intensely anthropogenic biome [38] that requires innovation in the face of current urbanisation trends [39-45]. We therefore prefixed GI with "urban" to denote its specific application to cities and used the term "urban green infrastructure" (UGI). Urban-green-infrastructure systems can transform traditional urban planning, governance, and policy and can help institutions tackle global challenges such as climate change, biodiversity loss, air pollution, water quantity and quality management, and aesthetics for human prosperity whilst en- 
hancing biodiversity outcomes [20,46]. This supporting infrastructure for urban-ecosystem services consists of the green areas of cities such as urban forests, parks, river systems, and urban ecology. In contrast to conventional mono-functional grey infrastructure, ecological or urban green infrastructure (UGI) is inherently multi-functional, productive, and resilient, leveraging the regenerative and complex characteristics of natural ecosystems [20,47]. The systems-based approach of UGI is well suited to the complexity and interconnected nature of the SDGs. UGI cuts across various goals and addresses multiple targets of the SDGs [26,48-50].

Scholars such as Caprioli et al. [51] and Cumming et al. [32] have encouraged urban governments, scientists, planners, and designers to look to the biological principles of the natural world as well as consider the synergistic use of energy and resources [52,53] to meet infrastructure needs in both a cost-effective and sustainable way. Urban green infrastructure can deliver ecosystem services to support growing cities whilst remaining within the natural carrying capacity of the environment [54-56].

Synthesis articles such as those by Johnson et al. [57] and Yang et al. [31] argue that ecosystem services can make significant contributions to the SDGs. The provision of food and water [58,59], the maintenance and conservation of habitats and biodiversity, climate regulation through carbon storage and sequestration, and other ecosystem services can all be delivered via ecosystem services [29]. Further, green infrastructure, which delivers ecosystem services is a significant multiplier that provides dividends for economies beyond the specific remit of particular urban-development projects. Water systems are particularly sensitive and reliant upon a healthy urban-green-infrastructure system $[60,61]$. However, Chung et al. [62] suggest that little global research has examined the intricate relationships between built and natural infrastructure for providing freshwater ecosystem services to cities across the globe. Equally with climate change, heat loads and energy consumption within cities will become more intense and stressed. UGI can help cities adapt and build resilience in the face of such energy-based pressures [53,63-65].

Ecosystem services are essential to achieving the SDGs. However, current anthropogenic practices have run down this natural capital. Urban development and design paradigms and infrastructure need to be radically reconsidered to address this deficit. The majority of nature's services provided are in a demonstrated decline worldwide [16]. Current prosperity and the infrastructure used to deliver it is unsustainable. Cross-cutting, transdisciplinary knowledge necessary to engineer and nurture a new, more ecologically sensitive urban world is essential [66].

To this end, this study reviewed the diverse literature on the SDGs and ecosystem services and examined its integration, strengths, and lacunae, with a particular focus on society's preparedness for urbanisation and the use of green infrastructure to address the urban SDG. The research was conducted through a theoretical contextualization, a critical review, and a systematic review using bibliometric network analysis to assess the centrality and connectedness of SDGs and ecosystem services concepts in the literature. Bibliometric analysis is necessary to assess the current state of complex transdisciplinary knowledge domains as noted by various researchers [67-70]. Sustainability is a transdisciplinary area that draws its significance and strength from connections and links between many domains rather than as an isolated disciplinary area. Network-based bibliometric analysis and mapping of science therefore captures these many links and connections and shows areas that are emerging or isolated and that need further development in relation to core principles and concepts. Bibliometric reviews therefore build on previous research and are useful to complete at periodic intervals in order to establish the state of science and to identify both successes and gaps for future research to address [71].

This approach echoes the structure of the SDGs, which have emerged as a form of network governance [72,73]. International mechanisms and cooperative initiatives such as the SDGs are important to spur action across various stakeholder groups such as researchers, communities, and local and national governments. To address the interactions between researchers and the SDGs, a systematic review was conducted using scientific literature of 
the past two decades from the Web of Science (WoS) database. Specifically, we asked the question: does existing research on ecosystem services support urban sustainability in the context of the SDGs? Further we asked: how can research on ecosystem services and cities "better support" the SDGs?

Three bodies of literature were reviewed (Figure 1) to address the challenge of urban sustainability as it relates to ecosystem services and cities.

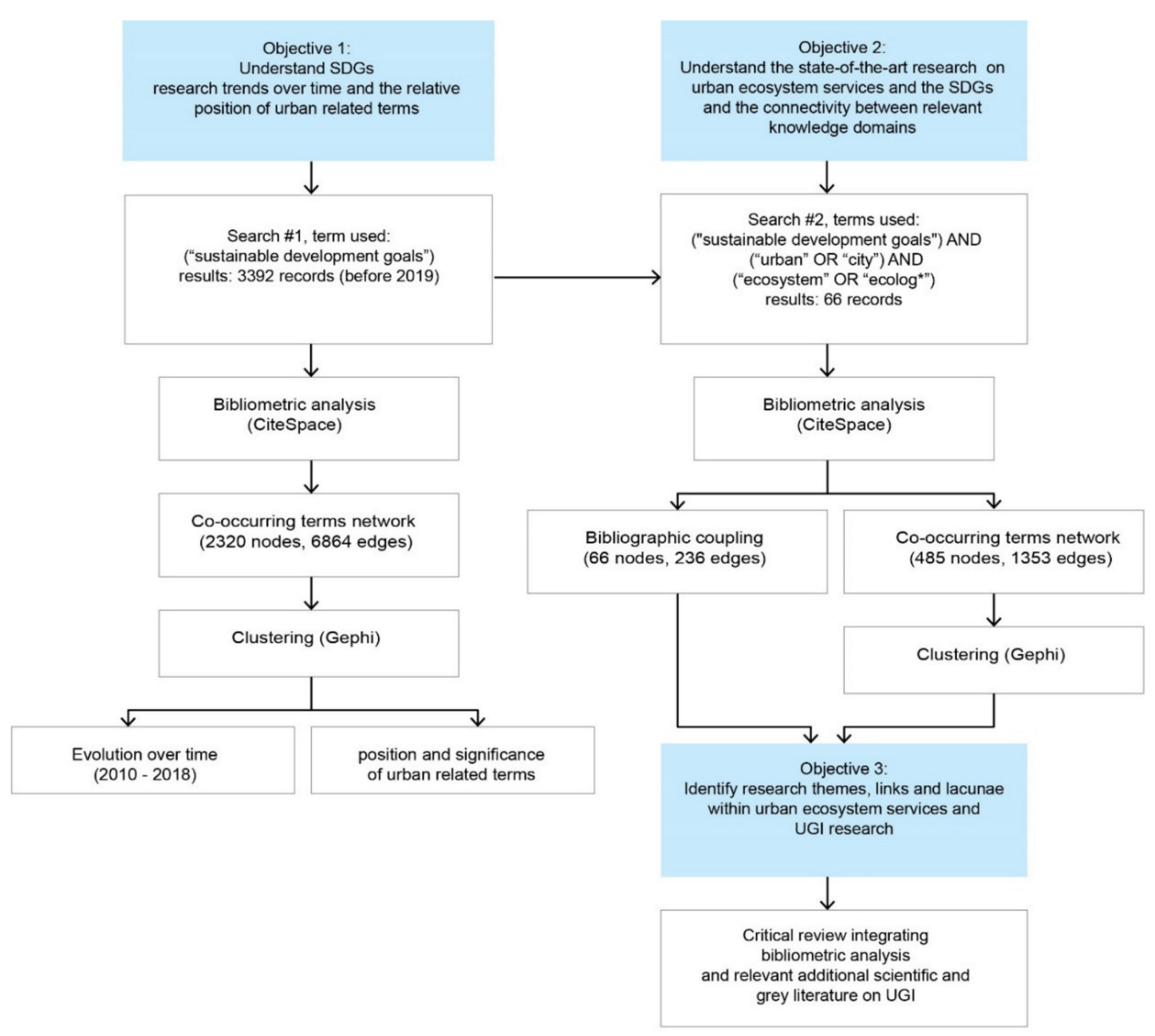

Figure 1. Research design and analytical methods (objectives 1, 2, and 3) to map current progress and readiness for implementing green infrastructure to achieve the Sustainable Development Goals (SDGs).

Firstly, we set out to assess current and emerging knowledge on: (i) the current evolving knowledge base of the SDGs as it relates to cities more generally; (ii) the knowledge base on cities, ecosystems, and SDGs to ascertain a contextual understanding; and (iii) the current knowledge base on UGI specifically. In relation to these bodies of literature, we asked the following three questions: (i) What are the SDG research trends and how have they changed over time? (ii) What is the state of research on urban ecosystem services, UGI, and the SDGs? and (iii) What knowledge gaps emerge through a critical review of urban-ecosystem services and their delivery through UGI in the context of the SDGs? Through this in-depth approach, we gathered knowledge to make recommendations on how to change the observed situation and better support the SDGs through urban green infra-structure.

\section{Materials and Methods}

Situating cities and ecosystem services within the broad area of sustainable development entails a comprehensive review of a large and growing body of literature. The 
transdisciplinary nature of research in this field calls for a holistic view rather than an isolated study of each sub-field. To this end, this study used bibliometric network analysis to extract significant topics, themes, and disciplines to best investigate their connections. Bibliometric analysis is an acknowledged approach for assessing the current state of research in scientific endeavours. It is therefore an effective method to assess science's contribution to the SDGs [74]. Various studies have used bibliometric analysis to understand different aspects of the SDGs focusing on topics such well-being and food security [68,75], but, as of yet, none cover SDGs, cities, and ecosystem services.

This study was designed to map progress in using ecosystem services to address city-based challenges within the SDG governance network (Figure 1).

As the sample for the study, we used the Web of Science Core Collection database, which is one of the world's largest scientific bibliographic databases covering over 21,100 international scientific journals [76]. Four levels of analysis were addressed to understand both the context and readiness of sustainability knowledge for achieving SDG 11 (Sustainable Cities and Communities). The first objective addressed the temporal and networkbased nature of knowledge on SDGs. The second objective placed SDG 11 in the context of the other SDGs, showing links to and from urban knowledge and its lacunae. The third objective focused on the subset of knowledge on ecosystem services, urban green infrastructure, and the SDGs. Finally, this network analysis was used, along with a critical review, to demonstrate the level of readiness for achieving the urban sustainability through green infrastructure and ecosystem services by identifying research themes, links, and lacunae.

Bibliometric network analysis allows for numerous approaches to understand the relationships between concepts and knowledge domains [77]. Bibliometric network analysis shifts the emphasis from discreet, silo-based measurements of knowledge to a better understanding of relationships between knowledge domains through a mapping of links and the connections between concepts, approaches, and features [78]. The shift from measuring to mapping is one of the characteristics of systems science [79]. In this study, CiteSpace [80], an open-source software package for bibliometric analysis, was used to generate connection maps. To explore the connectivity of concepts and structural gaps and lacunae [81], two types of analysis were used (Figure 2): (a) generating a bibliographic coupling where two publications that have used the same reference are connected (objectives 2 and 3) [82] and (b) generating a map of co-occurring terms, where terms that appear in the same title, within the same abstract, or in the same keyword list are connected (objectives 1,2, and 3 in Figure 1) [80].
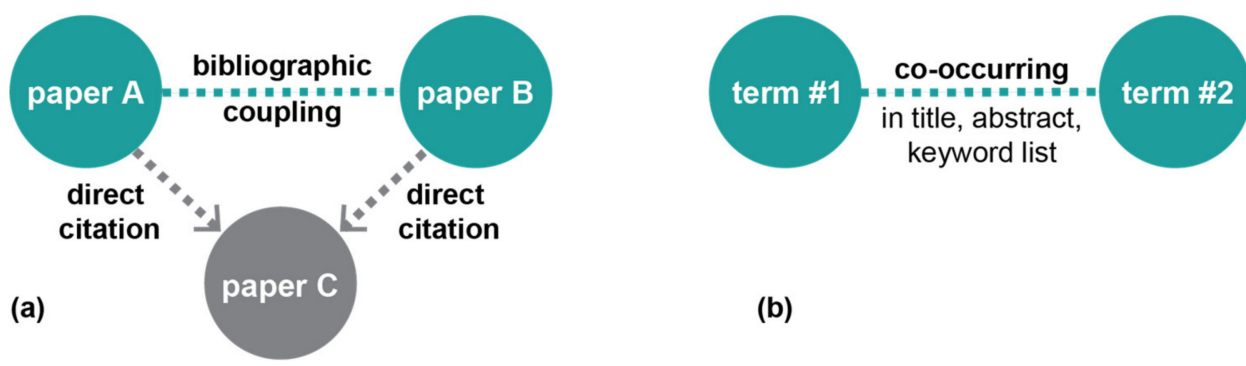

Figure 2. Two techniques of bibliometric analysis to generate maps of (a) bibliographic coupling (objectives 2 and 3 ) and (b) co-occurring terms (objectives 1, 2, and 3).

We used Gephi, a network analysis and visualisation software [83] to explore the connections of key concepts (such as "SDGs," "ecosystem services," and urban-related terms) using clustering methods [84]. We also conducted a quantitative analysis of the literature using graph metrics (i.e., betweenness centrality) [80]. Betweenness centrality quantifies the position of a node (term) in the network [85] and was used to identify key terms around which the network was formed. Nodes with high betweenness centrality are of great importance as they bridge gaps between clusters and provide inter-cluster links. 
These nodes are globally central and differ from local central nodes with a high degree of connectivity.

The bibliometric network analysis enabled us to advance our understanding of the field and identify emerging research trends. For objective 1, our analysis of the evolution of terms over time permitted insight into recent research trends (Figure 3). The position of major urban-related terms was highlighted to demonstrate how the urban SDG relates to other concepts and terms (Figure 3 and Table 1). For objective 2, following the network analysis, a critical review of the 66 studies was performed to understand key themes, links, and lacunae within the clusters. Finally, a critical review was conducted contextualising the analysed sample within key global policies, grey literature, and UGI research.

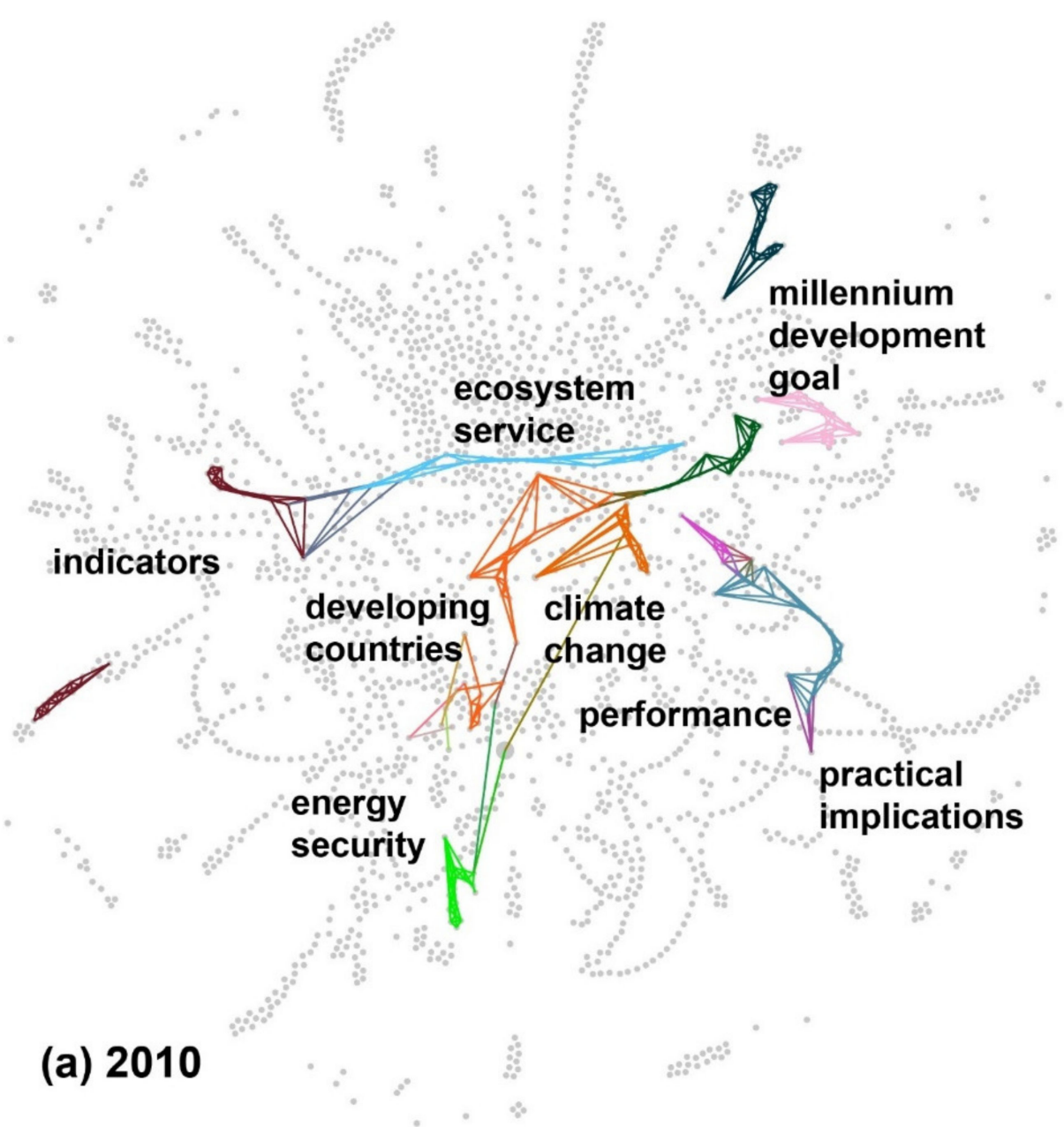

Figure 3. Cont. 

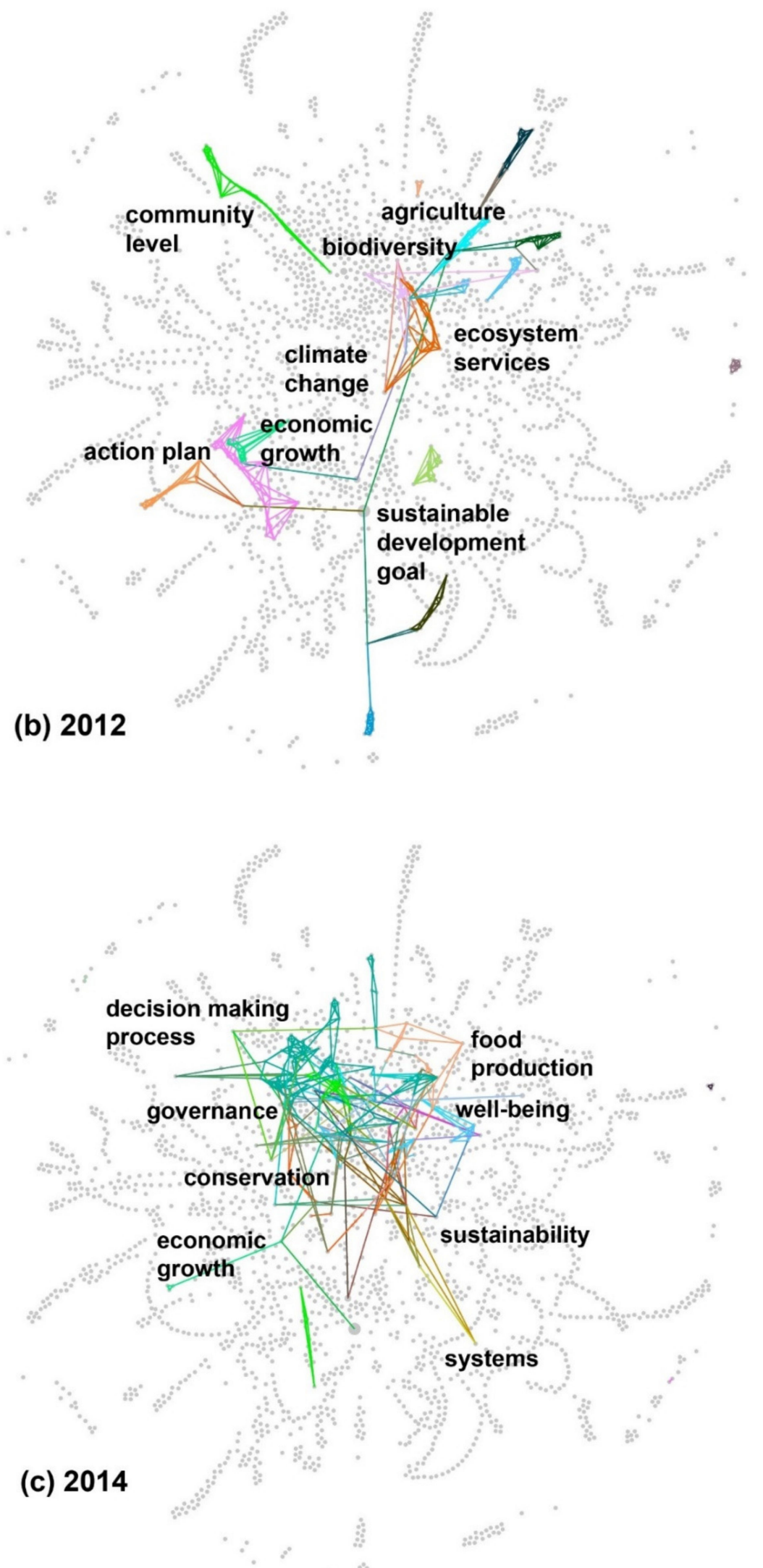

Figure 3. Cont. 

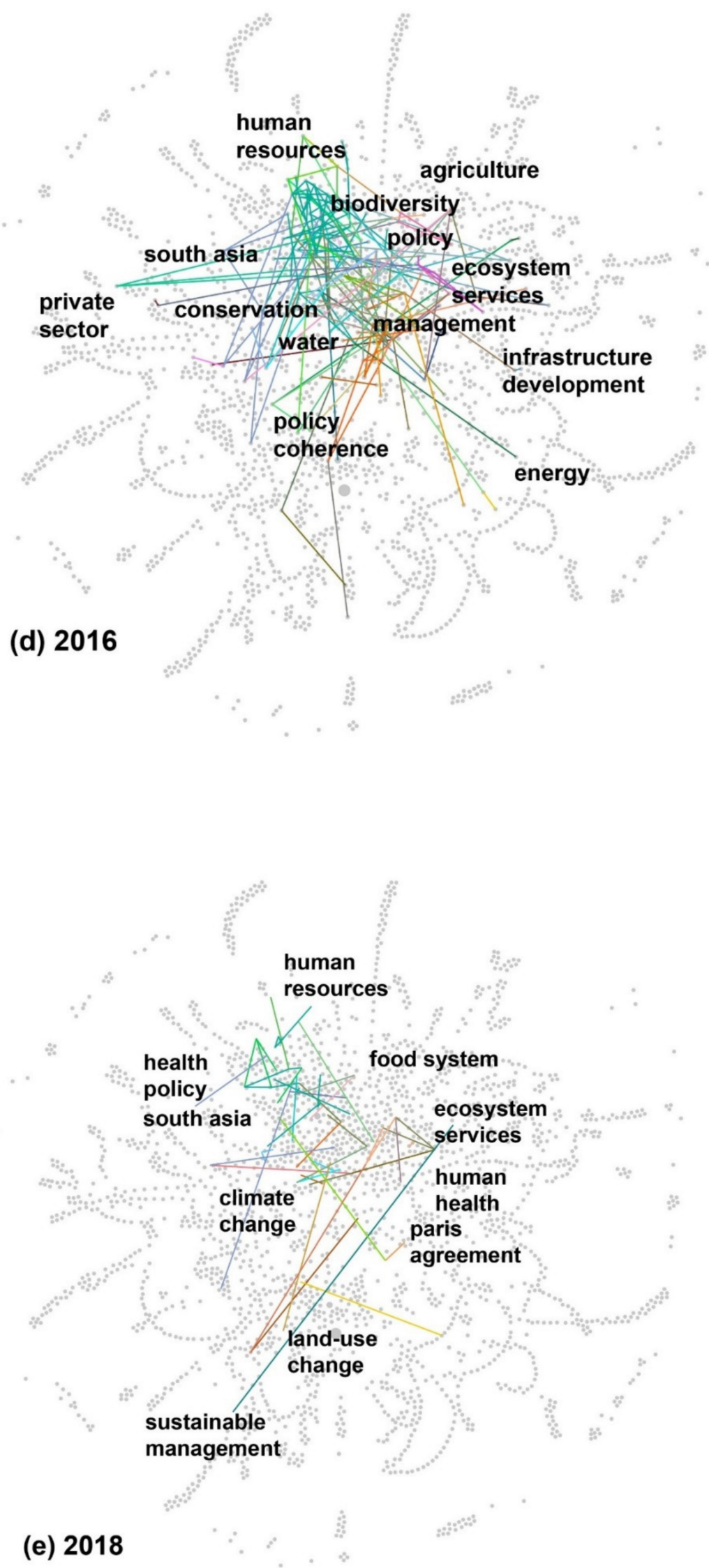

Figure 3. Cont. 


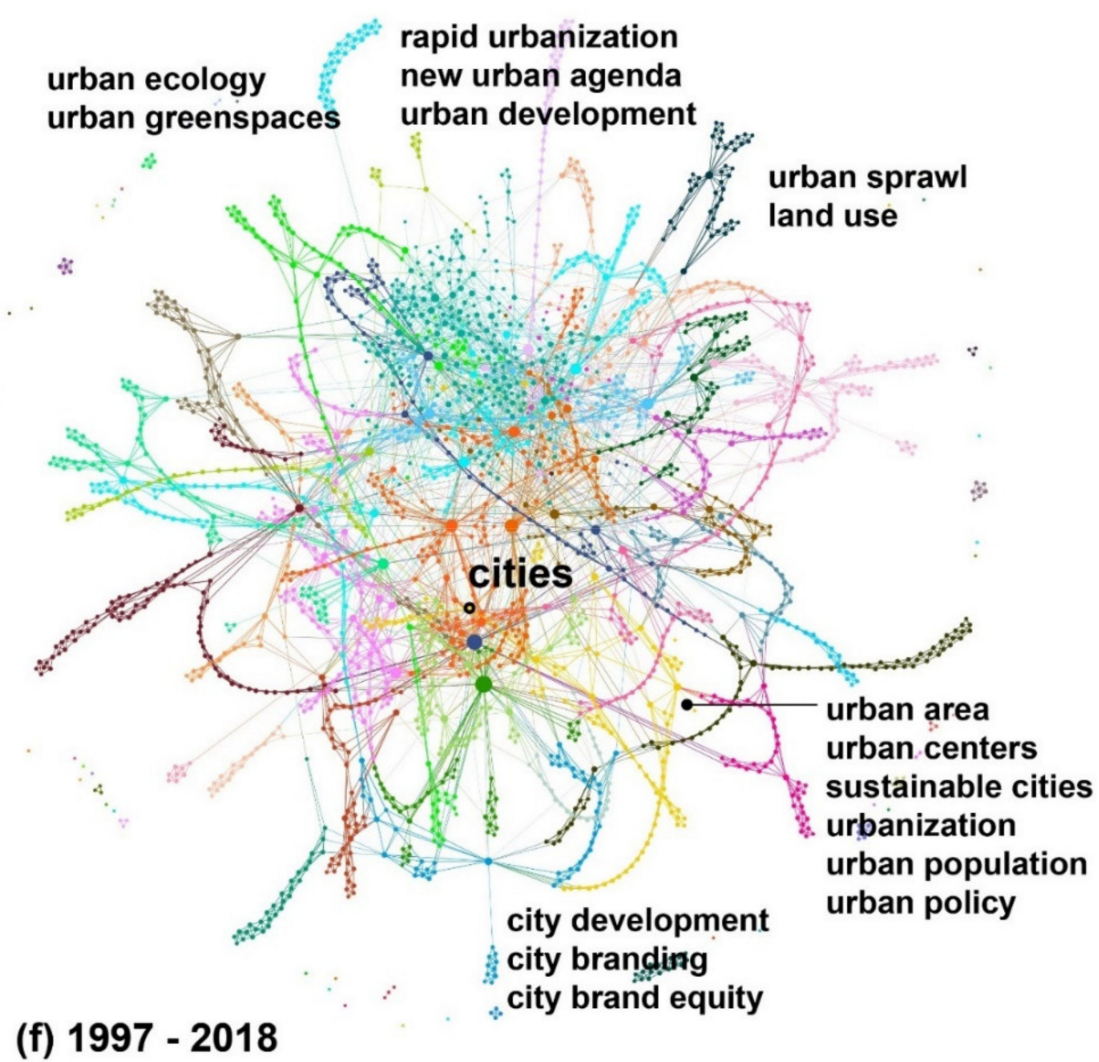

Figure 3. (a-f) The network of co-occurring search terms (objective 1) depicting research trends on the Sustainable Development Goals (a-e) from their development to the present at periodic intervals and (f) the overall shape of the co-occurring term network of all research between 1997 and 2018. The urban themed nodes are highlighted in each figure. It is apparent there was greater intensity of research in some years such as 2014 and 2016. Apparent also was the increasing complexity and peripheral nature of urban ecology and urban greenspaces relative to the collective body of knowledge (also see Table 1).

Table 1. List of top-45 urban-themed nodes/terms visualized in Figure 3 as a network of co-occurring terms (objective 1) ranked by their betweenness centrality.

\begin{tabular}{ccc}
\hline Term & Frequency & Betweenness Centrality \\
\hline Cities & 38 & 127,629 \\
\hline Urban area & 36 & 45,207 \\
\hline Rapid urbanisation & 4 & 11,444 \\
\hline Multi-district urban region & 1 & 10,978 \\
\hline City-based consumers & 1 & 10,869 \\
\hline City brand concept & 1 & 8802 \\
\hline Sustainable cities & 30 & 6702 \\
\hline New urban agenda & 20 & 6615 \\
\hline Leon city & 1 & 5519 \\
\hline Important urban green area & 1 & 5146 \\
\hline Coastal urban area & 1 & 5139 \\
\hline Private urban green space & 1 & 4740 \\
\hline City-based production & 1 & 4657 \\
\hline
\end{tabular}


Table 1. Cont.

\begin{tabular}{|c|c|c|}
\hline Term & Frequency & Betweenness Centrality \\
\hline City & 19 & 4010 \\
\hline Urban development pattern & 2 & 3509 \\
\hline City development & 2 & 3304 \\
\hline Tropical cities & 2 & 2436 \\
\hline $\begin{array}{c}\text { Traditional Latin-American } \\
\text { cities }\end{array}$ & 1 & 2337 \\
\hline Urban environmental system & 1 & 2330 \\
\hline Urban development & 19 & 2207 \\
\hline Northern cities & 1 & 2207 \\
\hline City branding & 1 & 2204 \\
\hline Urban centers & 3 & 2137 \\
\hline City operation & 1 & 1893 \\
\hline Urban center & 1 & 1872 \\
\hline $\begin{array}{c}\text { Expanding multi-district } \\
\text { urban area }\end{array}$ & 1 & 1872 \\
\hline Low-impact urban design & 1 & 1773 \\
\hline Urban change worldwide & 1 & 1593 \\
\hline Russian northern cities & 2 & 1343 \\
\hline City brand equity & 1 & 1104 \\
\hline City-port interface & 1 & 1101 \\
\hline Accelerating urban sprawl & 1 & 921 \\
\hline Fast-growing urban setting & 2 & 870 \\
\hline Accelerated urban sprawl & 1 & 497 \\
\hline Urban ethnography & 1 & 313 \\
\hline Urban population & 10 & 219 \\
\hline Connected cities & 1 & 7 \\
\hline Urban ecology & 1 & 5 \\
\hline Urbanization & 22 & 2 \\
\hline $\begin{array}{c}\text { Consumer-based city brand } \\
\text { equity }\end{array}$ & 1 & 2 \\
\hline Urban greenspaces & 1 & 1 \\
\hline Rapid urbanization & 15 & 0 \\
\hline Urban policy & 4 & 0 \\
\hline Urban air pollution & 2 & 0 \\
\hline Urban poor communities & 1 & 0 \\
\hline
\end{tabular}

\section{Results}

\subsection{Urban Themes in the Sustainable-Development-Goals Knowledge Base}

Since the conclusion of the MDGs, there has been increasing momentum surrounding the SDGs, and this is apparent from a temporal analysis within the Web of Science database, which is visualized in Figure 3 and Tables 1 and 2. A topic search of "sustainable development goals" in the Web of Science database in July 2018 resulted in 3392 records (Figure 1). The term "sustainable development goals" occurred as early as 1997, well before it was envisaged as a global governance structure [86]. By 2000, the term was linked with 
significant global environmental concerns such as "global warming," "energy system," "rising demand," "new millennium," "greenhouse gases," and "international community," but the terms were weakly connected (Figure 3a). A more-integrated network emerged over time (Figure 3a-e). Between 2010 and 2012, terms formed distinct clusters, whereas, between 2014 and 2016, term clusters began to form a more-tightly-integrated network. This development emerged from networks of relatively isolated clusters during the initial emergence of the SDGs that were slowly integrated through "bridging ties" (i.e., ties that are not linked to a specific knowledge domain but exist between term clusters).

Table 2. Number of edges and intra-edges (i.e., bridging ties) in networks filtered by year.

\begin{tabular}{cccc}
\hline Network & Number of Edges & Number of Intra-Edges & Percentage of Inter-Edges \\
\hline 2010 (Figure 3a) & 518 & 33 & 6.4 \\
2012 (Figure 3b) & 508 & 28 & 5.6 \\
2014 (Figure 3c) & 398 & 118 & 30 \\
2016 (Figure 3d) & 204 & 104 & 51 \\
2018 (Figure 3e) & 52 & 31 & 60 \\
\hline
\end{tabular}

A different colour was assigned to nodes and edges that shape a cluster, which is a group of highly connected nodes (Figure 3). Graphs (Figure 3a-e) depict all new connections of terms in a one-year period in 2010, 2012, 2014, 2016, and 2018. It also highlights central terms that have a high certain centrality and frequency of usage - such as: economic growth, climate change, developing countries, and biodiversity.

Table 2 shows the percentage of bridging ties in each time-based network. The goals were announced in 2015 (Figure 3c,d). The graph of co-occurring terms in 2018 indicated a decline in generating new connections compared to 2014 and 2016 (Figure 3e).

The cumulative image (Figure 3f) demonstrates the complexity and density of the overall SDG knowledge network. The knowledge clusters at the periphery of the network show various structures, with some more linear and some more centralised. Clusters at the centre of the network support SDGs more strongly than those at the periphery as they provide connections between otherwise disconnected nodes. Terms in peripheral clusters are connected (through one or multiple levels) with central cluster terms. Within the SDG term network, inter-cluster edges (i.e., bridging ties) constitute $13.2 \%$ of all edges in the graph, whereas intra-cluster edges (i.e., connections between nodes of a cluster) constitute $86.8 \%$ of connections. Despite their lesser quantity, bridging or inter-cluster edges integrate terms into an overall network. Edges between "cities" and "urban development" and "rapid urbanization" or the edges between "ecosystem service" and "conservation" and "biodiversity" are necessary to consider regarding SDG 11 as such urban terms were generally positioned at the periphery of the network (Figure $3 \mathrm{f}$ and Table 1) and were poorly connected to other thematic clusters with a low frequency of usage.

The investigation of the emergence of connections in the overall network revealed that, in 2003, the emergence of "cities" and "city" occurs with clear connections to core sustainability terms such as "environmental impacts" and "ecological footprint." Other terms that emerged in this period include "sustainable cities," "urban area," "poverty," and "urbanization." Among urban-related terms, "cities" is located at the centre of the network, providing bridging ties (Figure 3f). Connected to "cities" are terms such as "economic development," "population health," and "policymakers." The betweenness centrality of the "cities" node was ranked 10th among 2320 nodes, indicating its central position. As such, "cities" can be considered an anchor term that orientates research and links diverse research domains. Other terms (e.g., "city development," "urban area," "urbanization," "urban ecology," and "urban policy") were mostly located at the periphery of the network and were limited to their original clusters (Figure $3 \mathrm{f}$ and Table 1). Although ecological and green-associated themes featured in the analysis and are listed in Table 1, there is a notable absence of ecosystem services or equivalent or closely related terms such as biodiversity that are central and highly connected within the SDGs analytic network 
presented (Figure 3 and Table 1). This concerning lacuna will be followed up and examined later in the discussion section of the paper. Table 2 highlights that research intensity was greatest directly before and after the launch of the SDGs in 2015 with new intra edges or bridging ties peaking then falling off in 2018. This peak and decline of SDGs research is concerning and is also elaborated on further in the discussion.

\subsection{Urban-Ecosystem Services Themes in the Sustainable-Development-Goals Knowledge Base}

In this section, we present the results for both our bibliographic coupling analysis and our co-occurring-terms network analysis (see Figure 1 for the methodological process).

Based on the literature on SDGs and urban-ecosystem services (objective 2), the bibliographic coupling analysis revealed four internally and externally connected clusters as well as eleven independent studies not located within these clusters (Figure 4; Table 3). We found four emergent themes for these clusters. These included specific or specialized ecosystem services (cluster 1), ecosystem services in relation to a range of SDGs (cluster 2), urbanisation (cluster 3), resilience and sustainability (cluster 4), and diverse aspects of the SDGs tangential to ecosystem services (other clusters that were not well integrated) (Table 3).

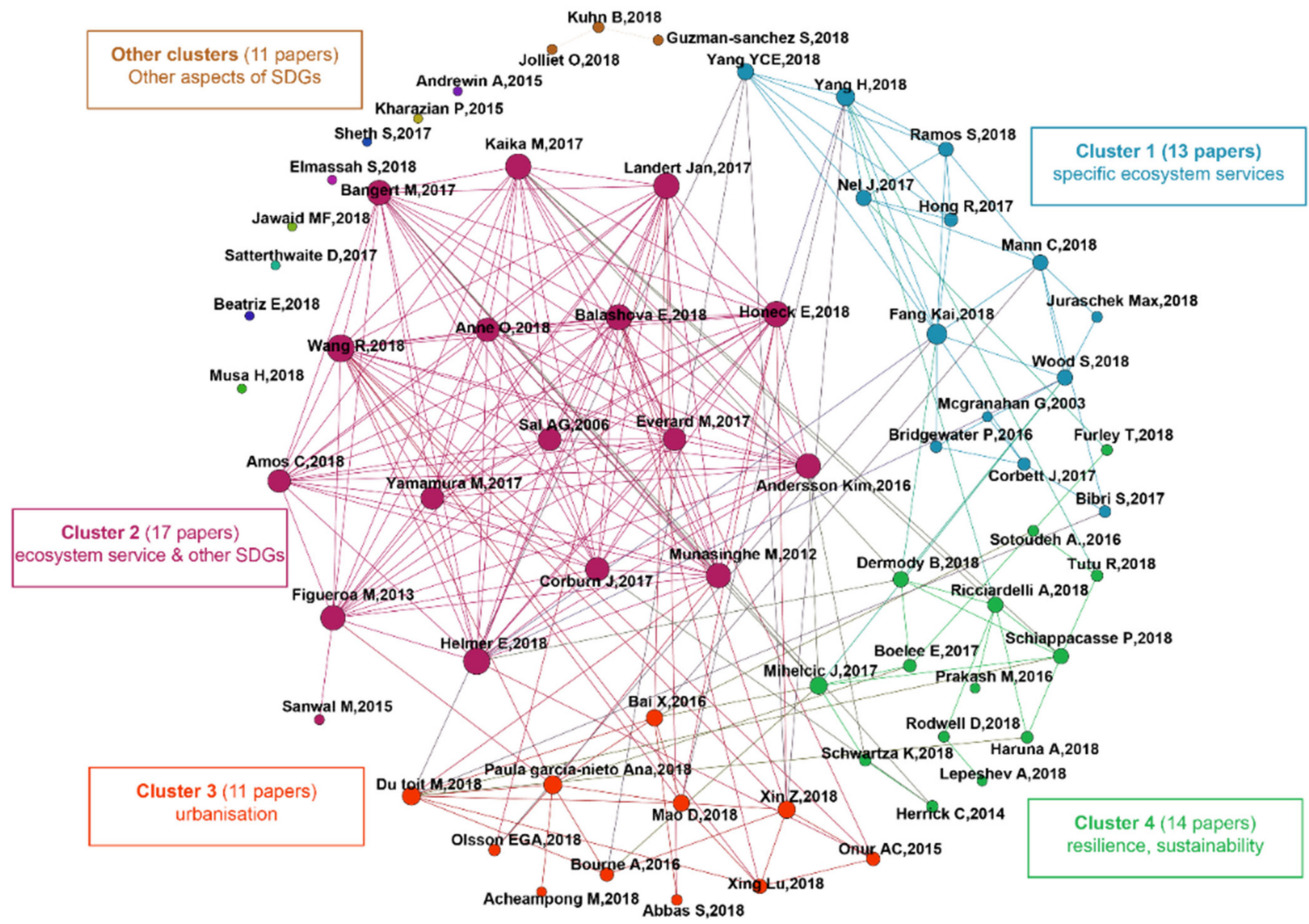

Figure 4. Network of 66 articles on the Sustainable Development Goals and urban-ecosystem services (objective 2) based on bibliographic coupling scores and cluster keywords extracted from a critical review. 
Table 3. Summary of the bibliographic coupling and critical review results of the 66 studies.

\begin{tabular}{|c|c|c|c|c|c|}
\hline & No. of Nodes & No. of Edges & Cluster Density * & Main Themes & Specific Topics \\
\hline $\begin{array}{c}\text { Cluster } 1 \\
\text { (13 studies) }\end{array}$ & 13 & 29 & 0.372 & $\begin{array}{c}\text { Ecosystem services } \\
\text { that contribute to } \\
\text { SDGs }\end{array}$ & $\begin{array}{l}\text { General ecosystem services } \\
\text { (Wood et al., 2018), social } \\
\text { (Ramos et al., 2018; Yang et al., } \\
\text { 2018), water (Fang et al., 2018; } \\
\text { Nel et al., 2017), urban (Bibri } \\
\text { and Krogstie, 2017; Juraschek } \\
\text { et al., 2018), and landscape } \\
\text { (Mann et al., 2018). }\end{array}$ \\
\hline $\begin{array}{c}\text { Cluster } 2 \\
\text { (17 studies) }\end{array}$ & 17 & 121 & 0.890 & $\begin{array}{l}\text { Diverse topics } \\
\text { beyond ecosystem } \\
\text { services that } \\
\text { contribute to SDG }\end{array}$ & $\begin{array}{l}\text { Health (Bangert et al., 2017; } \\
\text { Kaika, 2017), food (Landert } \\
\text { et al., 2017), energy (Anne et al., } \\
\text { 2018; Figueroa and Ribeiro, } \\
\text { 2013), and sanitation } \\
\text { (Andersson et al., 2016) }\end{array}$ \\
\hline $\begin{array}{c}\text { Cluster } 3 \\
\text { (11 studies) }\end{array}$ & 11 & 18 & 0.327 & $\begin{array}{l}\text { The impact of } \\
\text { urbanisation on } \\
\text { ecosystem services }\end{array}$ & $\begin{array}{l}\text { Land-use change (Acheampong } \\
\text { et al., 2018; Garcia-Nieto et al., } \\
\text { 2018), urban expansion (Mao } \\
\text { et al., 2018), landscape variation } \\
\text { (Abbas et al., 2018), GI } \\
\text { implementation (du Toit et al., } \\
\text { 2018) and climate change } \\
\text { (Bourne et al., 2016; Onur \& } \\
\text { Tezer, 2015). }\end{array}$ \\
\hline $\begin{array}{c}\text { Cluster } 4 \\
\text { (14 studies) }\end{array}$ & 14 & 16 & 0.176 & $\begin{array}{l}\text { Building resilience } \\
\text { and sustainability } \\
\text { to enhance } \\
\text { ecosystem services } \\
\text { and SDGs more } \\
\text { broadly }\end{array}$ & $\begin{array}{l}\text { Society (Tutu and Busingye, } \\
\text { 2018), food (Dermody et al., } \\
\text { 2018), water and GI (Boelee } \\
\text { et al., 2017; Haruna et al., 2018), } \\
\text { disaster (Ricciardelli et al., 2018), } \\
\text { regional and urban } \\
\text { development (Sotoudeh and } \\
\text { Parivar, 2016), and quality of } \\
\text { life (Prakash et al., 2016). }\end{array}$ \\
\hline $\begin{array}{c}\text { Other } \\
\text { clusters } \\
\text { (11 studies) }\end{array}$ & 11 & 2 & $\mathrm{~N} / \mathrm{A}$ & $\begin{array}{c}\text { Not-well- } \\
\text { connected studies } \\
\text { discussing various } \\
\text { SDG topics }\end{array}$ & $\begin{array}{l}\text { Health issues (Andrewin et al., } \\
\text { 2015; Beatriz et al., 2018; Sheth } \\
\text { and Ieee, 2017), tourism } \\
\text { (Kharazian, 2015), and } \\
\text { well-being (Musa et al., 2018) }\end{array}$ \\
\hline
\end{tabular}

* Cluster density quantifies how close the cluster is to complete. A complete cluster has all possible edges and density equal to 1.

Cluster 1 (blue dot studies in Figure 4) covered how ecosystem services can contribute to the SGDs from various perspectives (social, water, urban, etc.; Table 3). For example, Wood et al. [29] examined how integrating ecosystem services into the strategies for meeting SDGs can help to achieve human well-being; they also investigated how different ecosystem services can contribute to specific SDG targets. Cluster 2 (purple dot studies in Figure 4) contained the greatest number of studies and covered studies with diverse topics related to a range of SDGs and topics including ecosystem services but also health, food, energy, and sanitation aspects. For example, Andersson et al. [87] examined how sanitation can be approached from a "resource recovery perspective, generating added value to society while protecting human and ecosystem health." Cluster 3 (red dot studies in Figure 4) discussed how ecosystem services can be affected by different types of urbanisation, such as land-use change, urban expansion, implementation of GI, etc. (Table 2). For example, Mao et al [88] focused on urban wetlands (which provide multiple ecosystem services), investigated the amount and pattern of wetland loss in China due to urbanization, and found that the main cause was the expansion of urban built-up areas rather than industrial or transportation lands. Cluster 4 (green dot studies in Figure 4) contained studies on 
how building resilience and sustainability can enhance ecological services and SDGs from the aspects of society, food, water, GI, etc. (Table 2). Sotoudeh and Parivar [89] argue that we should apply resilience thinking to select more-sustainable urban-development scenarios to protect various scales of urban areas from ecological degradation due to urbanisation. Isolated studies (various colours in Figure 4) covered broader SDG topics (rather than only ecosystem services or SDG 11) such as health issues [90-92], tourism [93], and well-being [94].

The results of the co-occurring-terms network analysis are shown in Figure 5 and indicate major themes within two decades of literature on SDGs, cities, and ecosystems. Of note is the important linking characteristics of the term ecosystem services; however, it is relatively peripheral rather than central to the network. The network consists of 485 nodes (terms) and 1353 edges resulting in 17 clusters (indicated as different colours with the top 10 indicated in the figure key). The largest cluster ("sustainable cities") is located at the centre of the network and represents a relatively decentralised and interlocking structure in which there are multiple local central nodes. The second-largest cluster ("challenge") presents a general term that has been frequently used in the literature about urban ecological services and SDGs. The term "ecosystem service" represents the thirdlargest cluster, with a more tightly centralised structure. This cluster included terms such as "conservation," "sustainability," "indicators," and "new urban agenda." Although this cluster was located at the periphery of the overall network, "ecosystem service" ranked 11th in the overall network for betweenness centrality, providing bridging ties to the three other clusters "climate change," "challenges," and "sustainable cities." The other central term in the network, "climate change," was connected to five clusters other than its original cluster. Field-specific terms such as "sustainable tourism" and "health" formed the 8th and 10th largest clusters, respectively, and were positioned at the periphery of the network.

Table 4 provides more detailed information about top-10 largest clusters including the number of nodes (terms) and edges (connections between terms), as well as cluster density. The cluster density quantifies intra-cluster connections with regards to the number of possible edges. Cluster density increased as the clusters decrease in size. This indicates that terms are less connected to each other in large clusters, such as 'sustainable cities', 'challenges', and 'ecosystem service'.

Table 4 also depicts the dominant term in each cluster based on two metrics, betweenness centrality and frequency. This presents a more nuanced view of key themes in each cluster. While in some clusters such as Clusters 3, 4, 6, 9, and 10 the same term has been identified based on these two metrics, for the rest, the term with high betweenness centrality is different from the most frequent term in the cluster. For example, in Cluster 1 , 'sustainable cities' has the highest betweenness centrality and a central position in this cluster while 'sustainable development goals' is the most frequent term. In Cluster 2, 'challenges' is a central term based on betweenness centrality, however 'framework' and 'ecosystem services' are more frequently used in the sample dataset. Also, to have a fuller understanding of themes in each cluster, we present top ten terms based on their frequency.

Table 4. Characteristics of top-10 largest clusters and dominant terms in the network of co-occurring search terms (objective 2).

\begin{tabular}{ccccccc}
\hline $\begin{array}{c}\text { Cluster/Colour } \\
\text { as Appears in } \\
\text { Figure 5 }\end{array}$ & $\begin{array}{c}\text { No. of Nodes } \\
\text { (or Terms) }\end{array}$ & $\begin{array}{c}\text { No. of } \\
\text { Edges }\end{array}$ & $\begin{array}{c}\text { Cluster } \\
\text { Density }\end{array}$ & $\begin{array}{c}\text { Dominant } \\
\text { Term (Based on } \\
\text { Betweenness } \\
\text { Centrality) }\end{array}$ & $\begin{array}{c}\text { Dominant } \\
\text { Term (Based on } \\
\text { Frequency) }\end{array}$ & $\begin{array}{c}\text { Top Ten Terms (Based on } \\
\text { Frequency) }\end{array}$ \\
\hline 1 & 71 & 158 & 0.064 & $\begin{array}{c}\text { Sustainable } \\
\text { cities }\end{array}$ & $\begin{array}{c}\text { Sustainable } \\
\text { development } \\
\text { goals (17) }\end{array}$ & $\begin{array}{c}\text { Sustainable development goals; } \\
\text { sustainable cities; urbanization; } \\
\text { resilience; urban area; china; } \\
\text { urban; systems; vulnerability; } \\
\text { urban population }\end{array}$ \\
\hline
\end{tabular}


Table 4. Cont.

\begin{tabular}{|c|c|c|c|c|c|}
\hline $\begin{array}{l}\text { Cluster/Colour } \\
\text { as Appears in } \\
\text { Figure } 5\end{array}$ & $\begin{array}{l}\text { No. of Nodes } \\
\text { (or Terms) }\end{array}$ & $\begin{array}{l}\text { No. of } \\
\text { Edges }\end{array}$ & $\begin{array}{l}\text { Cluster } \\
\text { Density }\end{array}$ & $\begin{array}{c}\text { Dominant } \\
\text { Term (Based on } \\
\text { Betweenness } \\
\text { Centrality) }\end{array}$ & $\begin{array}{l}\text { Dominant } \\
\text { Term (Based or } \\
\text { Frequency) }\end{array}$ \\
\hline 2 & 61 & 145 & 0.079 & Challenges & $\begin{array}{l}\text { Framework; } \\
\text { ecosystem } \\
\text { services }(6)\end{array}$ \\
\hline 3 & 60 & 150 & 0.085 & $\begin{array}{c}\text { Ecosystem } \\
\text { service }\end{array}$ & $\begin{array}{l}\text { ecosystem } \\
\text { service (12) }\end{array}$ \\
\hline
\end{tabular}

\section{Top Ten Terms (Based on Frequency)}

Framework; ecosystem services; land-use; challenges; impact; human well-being; governance; multiple ecosystem service; urban sprawl; urban expansion

Ecosystem service; climate-change; conservation; sustainability; indicators; health service; new urban agenda; urban sustainability; services; economic development

Sustainable development goal; sustainable development; natural resources; sustainability goal; millennium development goals; millennium development goal; development; political ecology; public health; global health

development goal
Sustainable development goal (43)

Achieving sustainable development goal; city; ecological footprint; human development index; poverty; sub-national level;

Achieving sustainable development goal (4) environmental sustainability; environmental impacts; analytic hierarchy process; large proportion

Private propriety; paved surfaces; patio component;

$\begin{array}{lllll}6 & 34 & 93 & 0.166 & \text { Private }\end{array}$
propriety property (1) management pattern; leon city; patio model; plant uses; multifunctional categorization; leon municipality; important urban green area

public health; cities; developing countries; global sustainable

$\begin{array}{lllll}7 & 32 & 71 & 0.143 & \text { Cities }\end{array}$

Public health development goal; 21st century; sanitation; critical issues; African cities; sustainable industrial development; global community

Population growth; sustainable tourism; data-collection method; ecological conservation; educational level; external process; geo-tourism; ecotourism; different seasons; experimental research method 
Table 4. Cont.

\begin{tabular}{|c|c|c|c|c|c|c|}
\hline $\begin{array}{l}\text { Cluster/Colour } \\
\text { as Appears in } \\
\text { Figure } 5\end{array}$ & $\begin{array}{l}\text { No. of Nodes } \\
\text { (or Terms) }\end{array}$ & $\begin{array}{l}\text { No. of } \\
\text { Edges }\end{array}$ & $\begin{array}{l}\text { Cluster } \\
\text { Density }\end{array}$ & $\begin{array}{c}\text { Dominant } \\
\text { Term (Based on } \\
\text { Betweenness } \\
\text { Centrality) }\end{array}$ & $\begin{array}{l}\text { Dominant } \\
\text { Term (Based on } \\
\text { Frequency) }\end{array}$ & $\begin{array}{c}\text { Top Ten Terms (Based on } \\
\text { Frequency) }\end{array}$ \\
\hline 9 & 25 & 65 & 0.217 & Climate change & $\begin{array}{c}\text { Climate change } \\
\text { (11) }\end{array}$ & $\begin{array}{l}\text { Climate change; spatial } \\
\text { planning; additional } \\
\text { socio-ecological benefits; } \\
\text { addressing carbon-emission } \\
\text { management; aspirational } \\
\text { investment model positions; } \\
\text { climate-change scenario; } \\
\text { beneficial way; areas; adaptive } \\
\text { spatial policy development } \\
\text { process; addressing UN } \\
\text { sustainable development goal }\end{array}$ \\
\hline 10 & 22 & 60 & 0.260 & Health & Health (5) & $\begin{array}{l}\text { Health; evidence base; land use } \\
\text { pattern; deaths; floods; decadal } \\
\text { effect; investigating risk factor; } \\
\text { odds ratio; climate-related } \\
\text { disasters; climate-related } \\
\text { hazards }\end{array}$ \\
\hline
\end{tabular}

A critical review of the top-three-most-cited studies in the 66-study sample (Table 5) revealed their transdisciplinary and paradigm-shifting nature. The most-cited study, with 107 citations, was a review focusing on the futures of smart sustainable cities [95] included in cluster 1 of the bibliographic coupling network (Figure 4). When compared with other fields of study, 107 citations are not a significant amount of citations, demonstrating that urban sustainability science is an emerging field. The authors, Bibri and Krogstie, conducted a comprehensive review of the field of smart and sustainable cities and proposed an integrated approach to align existing problems and solution identification for future practices in smart sustainable urban planning and development [95]. This study discussed "sustainable cities" (the largest cluster in co-occurring terms) and also covered the majority of other terms in Figure 5 (e.g., challenges, ecosystem service, and SDGs). The secondmost-cited study by McGranahan and Satterthwaite [96] (with 75 citations) also appeared in cluster 1 of the bibliographic coupling network (Figure 4) and in the "sustainable cities" cluster of co-occurring terms (Figure 5). McGranahan and Satterthwaite's [96] study links terms such as ecological footprint, city, environmental impact, and city-based production while challenging mainstream approaches to urban sustainability. The authors argue for a focus on sustainable-development processes rather than the idealisation of sustainable cities as a goal in themselves for the reason that cities operate as part of a global system and therefore must demonstrate "concern for the environmental impact of urban-based production and consumption on the needs of all people, not just those within their jurisdiction." In this way, the authors radically expand our understanding of "urban sustainability" to operate across conventional temporal, spatial, social, and biological boundaries [96]. The third-most-cited paper by Kaika [97] with 38 citations appeared in cluster 2 of the bibliographic coupling network (Figure 4). Kaika [97] challenged the metric-driven and global-consensus-based emphasis of current sustainability and resilience efforts, instead advocating for greater attention to be given to dissenting community initiatives. Terms used in this study appeared in two clusters, "sustainable cities" and "ecosystem service," and included "resilience," "new urban agenda," "smart cities," "sustainability indicators," and "accessing housing." These three highly cited studies reflect major knowledge domains in this area (i.e., sustainable cities, ecosystem services, and SDGs) that were among the top-five-largest clusters identified in the co-occurring-term network analysis (Figure 5). Although all three studies significantly advance theoretical approaches to "international 
mechanisms" such as the sustainable development goals (SDGs), they do not explicitly mention UGI or address ecosystem services in a way that enables them to be applied to the challenge of smart and sustainable cities.

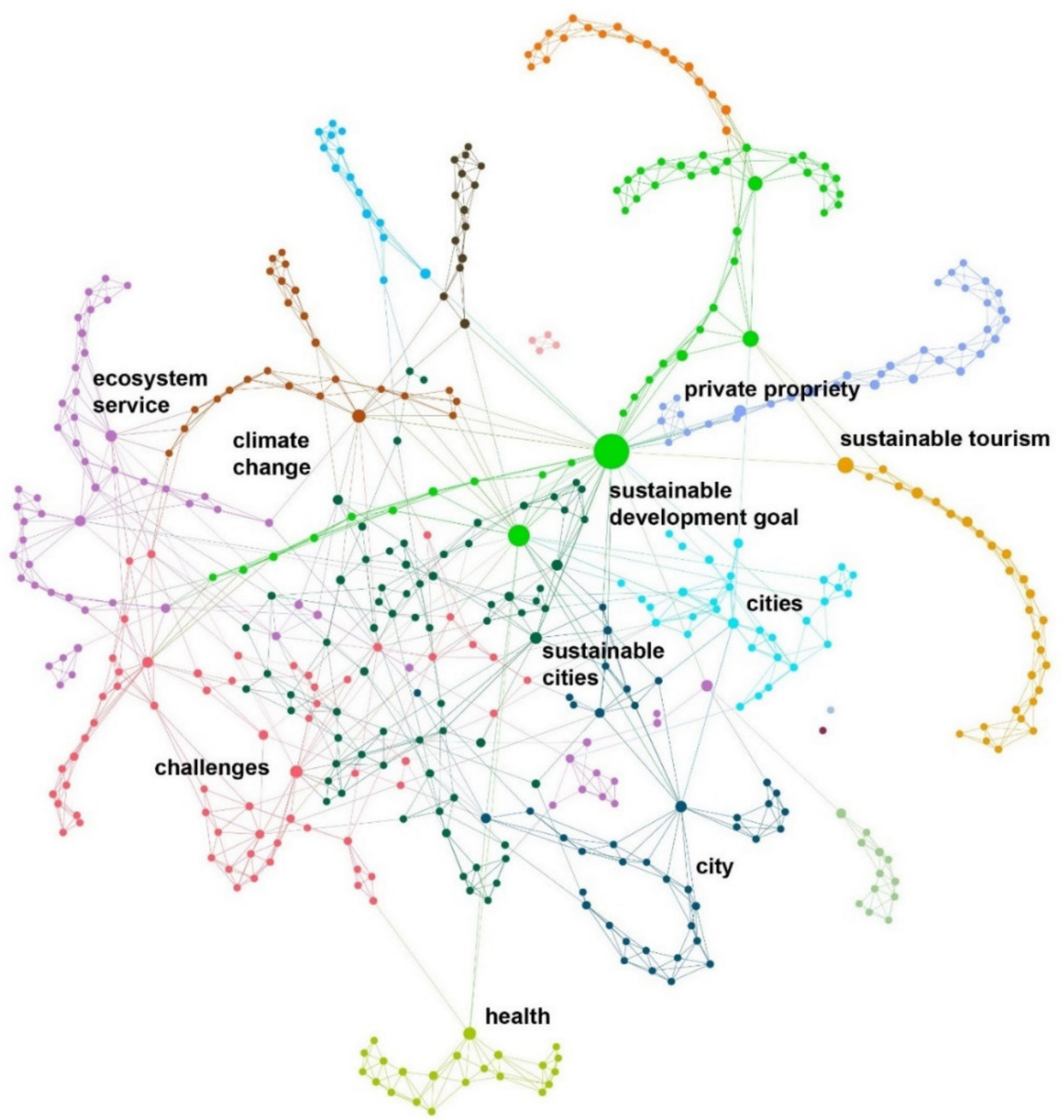

\section{Legend}

Cluster 1; sustainable cities

Cluster 2; challenges

Cluster 3; ecosystem service

Cluster 4; sustainable development goal

Cluster 5; city

Cluster 6; private propriety

Cluster 7; cities

Cluster 8; sustainable tourism

Cluster 9; climate change

Cluster 10; health

Figure 5. Network of co-occurring search terms (objective 2) and top-10 largest clusters. The size of the nodes represents betweenness centrality. To label each cluster, the term with the highest betweenness centrality was chosen. 
Table 5. Reference list of systematically reviewed studies from WoS.

\begin{tabular}{|c|c|c|c|c|}
\hline Authors & Year of Publication & Article Title & Journal/Book & Times Cited \\
\hline Abbas, S. et al. & 2018 & $\begin{array}{l}\text { SWOT analysis for socio-ecological } \\
\text { landscape variation as a precursor to } \\
\text { the management of the mountainous } \\
\text { Kanshi watershed, Salt Range of } \\
\text { Pakistan }\end{array}$ & $\begin{array}{l}\text { International Journal of } \\
\text { Sustainable Development } \\
\text { and World Ecology }\end{array}$ & 2 \\
\hline $\begin{array}{l}\text { Acheampong, } \mathrm{M} \text {. } \\
\text { et al. }\end{array}$ & 2018 & $\begin{array}{l}\text { Land use/cover change in Ghana's oil } \\
\text { city: Assessing the impact of } \\
\text { neoliberal economic policies and } \\
\text { implications for sustainable } \\
\text { development goal number one-A } \\
\text { remote sensing and GIS approach }\end{array}$ & Land Use Policy & 10 \\
\hline Amos, C. C. et al. & 2018 & $\begin{array}{l}\text { A scoping review of roof harvested } \\
\text { rainwater usage in urban agriculture: } \\
\text { Australia and Kenya in focus }\end{array}$ & $\begin{array}{l}\text { Journal of Cleaner } \\
\text { Production }\end{array}$ & 3 \\
\hline Andersson, K. et al. & 2016 & $\begin{array}{c}\text { Towards "Sustainable" Sanitation: } \\
\text { Challenges and Opportunities in } \\
\text { Urban Areas }\end{array}$ & Sustainability & 12 \\
\hline $\begin{array}{l}\text { Andrewin, A. N. } \\
\quad \text { et al. }\end{array}$ & 2015 & $\begin{array}{l}\text { Determinants of the lethality of } \\
\text { climate-related disasters in the } \\
\text { Caribbean Community (CARICOM): a } \\
\text { cross-country analysis }\end{array}$ & Scientific Reports & 1 \\
\hline Anne, O. et al. & 2018 & $\begin{array}{l}\text { The water resources circularity and } \\
\text { energy efficiency at the wastewater } \\
\text { treatment plant of the seaport city }\end{array}$ & $\begin{array}{l}2018 \text { IEEE/Oes Baltic } \\
\text { International Symposium }\end{array}$ & 0 \\
\hline Bai, X. M. et al. & 2016 & $\begin{array}{l}\text { Defining and advancing a systems } \\
\text { approach for sustainable cities }\end{array}$ & $\begin{array}{l}\text { Current Opinion in } \\
\text { Environmental } \\
\text { Sustainability }\end{array}$ & 55 \\
\hline $\begin{array}{l}\text { Balashova, E. } \\
\text { Sharipova, S. }\end{array}$ & 2018 & $\begin{array}{c}\text { Impact of ecosystem services on a } \\
\text { sustainable business strategy in urban } \\
\text { conditions }\end{array}$ & $\begin{array}{l}\text { International Science } \\
\text { Conference } \\
\text { Spbwosce-2017 Business } \\
\text { Technologies for } \\
\text { Sustainable Urban } \\
\text { Development }\end{array}$ & 0 \\
\hline Bangert, M. et al. & 2017 & $\begin{array}{l}\text { The cross-cutting contribution of the } \\
\text { end of neglected tropical diseases to } \\
\text { the sustainable development goals }\end{array}$ & $\begin{array}{l}\text { Infectious Diseases of } \\
\text { Poverty }\end{array}$ & 40 \\
\hline Beatriz, E. D. et al. & 2018 & $\begin{array}{l}\text { Urban-rural disparity and urban } \\
\text { population growth: A multilevel } \\
\text { analysis of under-5 mortality in } 30 \\
\text { sub-Saharan African countries }\end{array}$ & Health \& Place & 1 \\
\hline $\begin{array}{l}\text { Bibri, S. E. } \\
\text { Krogstie, J. }\end{array}$ & 2017 & $\begin{array}{l}\text { Smart sustainable cities of the future: } \\
\text { An extensive interdisciplinary } \\
\text { literature review }\end{array}$ & $\begin{array}{l}\text { Sustainable Cities and } \\
\text { Society }\end{array}$ & 157 \\
\hline Boelee, E. et al. & 2017 & $\begin{array}{l}\text { Overcoming water challenges through } \\
\text { nature-based solutions }\end{array}$ & Water Policy & 3 \\
\hline Bourne, A. et al. & 2016 & $\begin{array}{l}\text { A Socio-Ecological Approach for } \\
\text { Identifying and Contextualising } \\
\text { Spatial Ecosystem-Based Adaptation } \\
\text { Priorities at the Sub-National Level }\end{array}$ & Plos One & 11 \\
\hline $\begin{array}{l}\text { Bridgewater, P. } \\
\text { Arico, S. }\end{array}$ & 2016 & $\begin{array}{l}\text { Turbo-charging the Ecohydrology } \\
\text { paradigm for the Anthropocene }\end{array}$ & $\begin{array}{l}\text { Ecohydrology \& } \\
\text { Hydrobiology }\end{array}$ & 2 \\
\hline
\end{tabular}


Table 5. Cont.

\begin{tabular}{|c|c|c|c|c|}
\hline Authors & Year of Publication & Article Title & Journal/Book & Times Cited \\
\hline $\begin{array}{l}\text { Corbett, J. } \\
\text { Mellouli, S. }\end{array}$ & 2017 & $\begin{array}{l}\text { Winning the SDG battle in cities: how } \\
\text { an integrated information ecosystem } \\
\text { can contribute to the achievement of } \\
\text { the } 2030 \text { sustainable development } \\
\text { goals }\end{array}$ & $\begin{array}{l}\text { Information Systems } \\
\text { Journal }\end{array}$ & 9 \\
\hline Corburn, J. & 2017 & $\begin{array}{l}\text { Urban Place and Health Equity: } \\
\text { Critical Issues and Practices }\end{array}$ & $\begin{array}{l}\text { International Journal of } \\
\text { Environmental Research } \\
\text { and Public Health }\end{array}$ & 13 \\
\hline Dermody, B. J. et al. & 2018 & $\begin{array}{l}\text { A framework for modelling the } \\
\text { complexities of food and water } \\
\text { security under globalisation }\end{array}$ & Earth System Dynamics & 10 \\
\hline du Toit, M. J. et al. & 2018 & $\begin{array}{c}\text { Urban green infrastructure and } \\
\text { ecosystem services in sub-Saharan } \\
\text { Africa }\end{array}$ & $\begin{array}{l}\text { Landscape and Urban } \\
\text { Planning }\end{array}$ & 17 \\
\hline ElMassah, S. & 2018 & $\begin{array}{c}\text { Industrial symbiosis within } \\
\text { eco-industrial parks: Sustainable } \\
\text { development for Borg El-Arab in } \\
\text { Egypt }\end{array}$ & $\begin{array}{l}\text { Business Strategy and the } \\
\text { Environment }\end{array}$ & 3 \\
\hline Everard, M. et al. & 2017 & $\begin{array}{l}\text { Developed-developing world } \\
\text { partnerships for sustainable } \\
\text { development (2): An illustrative case } \\
\text { for a payments for ecosystem services } \\
\text { (PES) approach }\end{array}$ & Ecosystem Services & 1 \\
\hline Fang, K. et al. & 2018 & $\begin{array}{c}\text { Sustainability of the use of natural } \\
\text { capital in a city: Measuring the size } \\
\text { and depth of urban ecological and } \\
\text { water footprints }\end{array}$ & $\begin{array}{l}\text { Science of the Total } \\
\text { Environment }\end{array}$ & 12 \\
\hline $\begin{array}{l}\text { Figueroa, M. J. } \\
\text { Ribeiro, S. K. }\end{array}$ & 2013 & $\begin{array}{c}\text { Energy for road passenger transport } \\
\text { and sustainable development: } \\
\text { assessing policies and goals } \\
\text { interactions }\end{array}$ & $\begin{array}{l}\text { Current Opinion in } \\
\text { Environmental } \\
\text { Sustainability }\end{array}$ & 11 \\
\hline Furley, T. H. et al. & 2018 & $\begin{array}{c}\text { Toward sustainable environmental } \\
\text { quality: Identifying priority research } \\
\text { questions for Latin America }\end{array}$ & $\begin{array}{l}\text { Integrated } \\
\text { Environmental } \\
\text { Assessment and } \\
\text { Management }\end{array}$ & 19 \\
\hline $\begin{array}{l}\text { Garcia-Nieto, A. P. } \\
\text { et al. }\end{array}$ & 2018 & $\begin{array}{l}\text { Impacts of urbanization around } \\
\text { Mediterranean cities: Changes in } \\
\text { ecosystem service supply }\end{array}$ & Ecological Indicators & 16 \\
\hline $\begin{array}{l}\text { Guzman-Sanchez, S. } \\
\text { et al. }\end{array}$ & 2018 & $\begin{array}{l}\text { Assessment of the contributions of } \\
\text { different flat roof types to achieving } \\
\text { sustainable development }\end{array}$ & $\begin{array}{l}\text { Building and } \\
\text { Environment }\end{array}$ & 8 \\
\hline Haruna, A. I. et al. & 2018 & $\begin{array}{c}\text { Exploring eco-aesthetics for urban } \\
\text { green infrastructure development and } \\
\text { building resilient cities: A theoretical } \\
\text { overview }\end{array}$ & Cogent Social Sciences & 0 \\
\hline Helmer, E. H. et al. & 2018 & $\begin{array}{l}\text { Tropical Deforestation and } \\
\text { Recolonization by Exotic and Native } \\
\text { Trees: Spatial Patterns of Tropical } \\
\text { Forest Biomass, Functional Groups, } \\
\text { and Species Counts and Links to } \\
\text { Stand Age, Geoclimate, and } \\
\text { Sustainability Goals }\end{array}$ & Remote Sensing & 4 \\
\hline
\end{tabular}


Table 5. Cont.

\begin{tabular}{|c|c|c|c|c|}
\hline Authors & Year of Publication & Article Title & Journal/Book & Times Cited \\
\hline Herrick, C. & 2014 & $\begin{array}{l}\text { (Global) health geography and the } \\
\text { post-2015 development agenda }\end{array}$ & Geographical Journal & 11 \\
\hline Honeck, E. et al. & 2018 & $\begin{array}{l}\text { From a Vegetation Index to a } \\
\text { Sustainable Development Goal } \\
\text { Indicator: Forest Trend Monitoring } \\
\text { Using Three Decades of Earth } \\
\text { Observations across Switzerland }\end{array}$ & $\begin{array}{l}\text { Isprs International } \\
\text { Journal of } \\
\text { Geo-Information }\end{array}$ & 4 \\
\hline Hong, R. et al. & 2017 & $\begin{array}{l}\text { The unfinished health agenda: } \\
\text { Neonatal mortality in Cambodia }\end{array}$ & Plos One & 3 \\
\hline Jawaid, M. F. et al. & 2018 & $\begin{array}{c}\text { Environmental Responsive Urban } \\
\text { Planning and Regulations in India: An } \\
\text { Analysis }\end{array}$ & $\begin{array}{l}\text { Urbanization Challenges } \\
\text { in Emerging Economies: } \\
\text { Energy and Water } \\
\text { Infrastructure; } \\
\text { Transportation } \\
\text { Infrastructure; and } \\
\text { Planning and Financing }\end{array}$ & 0 \\
\hline
\end{tabular}

Jolliet, O. et al. 2018 impacts of climate change, fine particulate matter formation, water consumption and land use

Urban factories and their potential contribution to the sustainable development of cities
International Journal of

Life Cycle Assessment

25th Cirp Life Cycle Engineering

'Don't call me resilient again!': the

New Urban Agenda as immunology

Kaika, M.

2017

Kharazian, P.

Landert, J. et al.

2017

Lepeshev, A. et al.

2018
... or ... what happens when communities refuse to be vaccinated with 'smart cities' and indicators

Assessment of Geo-Tourism Structure

in Bojnoord City Sustainable Tourism Development

China's Commitment to the

Sustainable Development Goals: An

Analysis of Push and Pull Factors and

Implementation Challenges

A Holistic Sustainability Assessment Method for Urban Food System Governance

Ecological engineering of the sixth innovation wave in system of

continuous training and Municipal Facilities Development

Environment and

Urbanization

64

European Journal of Sustainable Development

Chinese Political Science Review

0

Sustainability

International Science

Conference

Spbwosce-2017 Business

Technologies for

Sustainable Urban

Development

The potential for integrated landscape management to fulfil Europe's commitments to the Sustainable Development Goals

China's wetlands loss to urban expansion
Landscape and Urban Planning
Land Degradation \& Development
Mann, C. et al.

Mao, D. H. et al.

2018 
Table 5. Cont.

\begin{tabular}{|c|c|c|c|c|}
\hline Authors & Year of Publication & Article Title & Journal/Book & Times Cited \\
\hline $\begin{array}{l}\text { McGranahan, G. } \\
\text { Satterthwaite, D. }\end{array}$ & 2003 & $\begin{array}{c}\text { Urban centers: An assessment of } \\
\text { sustainability }\end{array}$ & $\begin{array}{l}\text { Annual Review of } \\
\text { Environment and } \\
\text { Resources }\end{array}$ & 80 \\
\hline Mihelcic, J. R. et al. & 2017 & $\begin{array}{c}\text { The Grandest Challenge of All: The } \\
\text { Role of Environmental Engineering to } \\
\text { Achieve Sustainability in the World's } \\
\text { Developing Regions }\end{array}$ & $\begin{array}{l}\text { Environmental } \\
\text { Engineering Science }\end{array}$ & 16 \\
\hline Munasinghe, $\mathrm{M}$. & 2012 & $\begin{array}{l}\text { Millennium Consumption Goals } \\
\text { (MCGs) for Rio+20 and beyond: A } \\
\text { practical step towards global } \\
\text { sustainability }\end{array}$ & Natural Resources Forum & 9 \\
\hline
\end{tabular}

$\begin{array}{ccc}\text { Enhancing subjective well-being } & \text { Sustainable Cities and } \\ \text { Musa, H. D. et al. } & 2018 & \begin{array}{c}\text { Shough strategic urban planning: } \\ \text { Development and application of } \\ \text { community happiness index }\end{array}\end{array}$

Nel, J. L. et al.

2017

water security: Making the connection

between protecting ecosystems and benefiting from their services

\begin{tabular}{|c|c|c|c|c|}
\hline Olsson, E. G. A. & 2018 & $\begin{array}{l}\text { Urban food systems as vehicles for } \\
\text { sustainability transitions }\end{array}$ & $\begin{array}{l}\text { Bulletin of Geography- } \\
\text { Socio-Economic } \\
\text { Series }\end{array}$ & 2 \\
\hline $\begin{array}{l}\text { Onur, A. C. } \\
\text { Tezer, A. }\end{array}$ & 2015 & $\begin{array}{l}\text { Ecosystem services based spatial } \\
\text { planning decision making for } \\
\text { adaptation to climate changes }\end{array}$ & Habitat International & 7 \\
\hline Prakash, M. et al. & 2016 & $\begin{array}{l}\text { Multi-criteria approach to } \\
\text { geographically visualize the quality of } \\
\text { life in India }\end{array}$ & $\begin{array}{l}\text { International Journal of } \\
\text { Sustainable Development } \\
\text { and World Ecology }\end{array}$ & 3 \\
\hline Ramos, S. B. et al. & 2018 & $\begin{array}{l}\text { Prediction of Human Development } \\
\text { from Environmental Indicators }\end{array}$ & $\begin{array}{l}\text { Social Indicators } \\
\text { Research }\end{array}$ & 2 \\
\hline Ricciardelli, A. et al. & 2018 & $\begin{array}{l}\text { Impacts for implementing SDGs: } \\
\text { sustainable collaborative communities } \\
\text { after disasters. The city of Macerata at } \\
\text { the aftermath of the earthquake }\end{array}$ & $\begin{array}{c}\text { Corporate } \\
\text { Governance-the } \\
\text { International Journal of } \\
\text { Business in Society }\end{array}$ & 1 \\
\hline Rodwell, D. & 2018 & $\begin{array}{l}\text { The Historic Urban Landscape and the } \\
\text { Geography of Urban Heritage }\end{array}$ & $\begin{array}{l}\text { Historic } \\
\text { Environment-Policy \& } \\
\text { Practice }\end{array}$ & 3 \\
\hline Sal, A. G. et al. & 2006 & $\begin{array}{l}\text { Private patios, a valuable hidden } \\
\text { heritage for tourism development in } \\
\text { the city of Leon, Nicaragua }\end{array}$ & Sustainable Tourism II & 2 \\
\hline Sanwal, M. & 2015 & $\begin{array}{l}\text { Global sustainable development goals } \\
\text { are about the use and distribution, not } \\
\text { scarcity of natural resources: will the } \\
\text { middle class in the USA, China and } \\
\text { India save the climate as its incomes } \\
\text { grow? }\end{array}$ & $\begin{array}{l}\text { Climate and } \\
\text { Development }\end{array}$ & 0 \\
\hline Satterthwaite, D. & 2017 & $\begin{array}{l}\text { Will Africa have most of the world's } \\
\text { largest cities in } 2100 ?\end{array}$ & $\begin{array}{l}\text { Environment and } \\
\text { Urbanization }\end{array}$ & 3 \\
\hline $\begin{array}{l}\text { Schiappacasse, P. } \\
\text { Muller, B. }\end{array}$ & 2018 & $\begin{array}{l}\text { One fits all? Resilience as a } \\
\text { Multipurpose Concept in Regional } \\
\text { and Environmental Development }\end{array}$ & $\begin{array}{l}\text { Raumforschung Und } \\
\text { Raumordnung-Spatial } \\
\text { Research and Planning }\end{array}$ & 0 \\
\hline
\end{tabular}


Table 5. Cont.

\begin{tabular}{|c|c|c|c|c|}
\hline Authors & Year of Publication & Article Title & Journal/Book & Times Cited \\
\hline Schwartza, K. et al. & 2018 & $\begin{array}{c}\text { Editorial-Inclusive development and } \\
\text { urban water services }\end{array}$ & Habitat International & 0 \\
\hline Sheth, S. & 2017 & $\begin{array}{c}\text { The TripleRM Global Health } \\
\text { Management Model (GHMM): } \\
\text { Strategic Risk Management of Vector } \\
\text { Borne Infectious Diseases to Build } \\
\text { Healthy, Sustainable, Adaptable and } \\
\text { Resilient Communities (Strategic } \\
\text { Global Health Security Risk } \\
\text { Assessment, Resilience Planning And } \\
\text { Resource Management in Urban and } \\
\text { Rural Environments) }\end{array}$ & $\begin{array}{l}2017 \text { IEEE Conference on } \\
\text { Technologies for } \\
\text { Sustainability }\end{array}$ & 0 \\
\hline $\begin{array}{l}\text { Sotoudeh, A. } \\
\text { Parivar, P. }\end{array}$ & 2016 & $\begin{array}{l}\text { Applying resilience thinking to select } \\
\text { more sustainable urban development } \\
\text { scenarios in Shiraz, Iran }\end{array}$ & Scientia Iranica & 0 \\
\hline $\begin{array}{l}\text { Tutu, R. } \\
\text { Busingye, J. D. }\end{array}$ & 2018 & $\begin{array}{l}\text { Building Resilient Societies in Africa } \\
\text { for the Future: Conceptual } \\
\text { Considerations and Possible } \\
\text { Resilience Constituents }\end{array}$ & $\begin{array}{l}\text { Journal of Futures } \\
\text { Studies }\end{array}$ & 0 \\
\hline Wang, R. et al. & 2018 & $\begin{array}{c}\text { Scenario-Based Simulation of Tianjin } \\
\text { City Using a Cellular } \\
\text { Automata-Markov Model }\end{array}$ & Sustainability & 3 \\
\hline Wood, S. L. R. et al. & 2018 & $\begin{array}{l}\text { Distilling the role of ecosystem } \\
\text { services in the Sustainable } \\
\text { Development Goals }\end{array}$ & Ecosystem Services & 45 \\
\hline Xin, Z. H. et al. & 2018 & $\begin{array}{l}\text { Evaluation of Temporal and Spatial } \\
\text { Ecosystem Services in Dalian, China: } \\
\text { Implications for Urban Planning }\end{array}$ & Sustainability & 2 \\
\hline Xing, L. et al. & 2018 & $\begin{array}{l}\text { Spatial correction of ecosystem service } \\
\text { value and the evaluation of } \\
\text { eco-efficiency: A case for China's } \\
\text { provincial level }\end{array}$ & Ecological Indicators & 3 \\
\hline Yamamura, M. et al. & 2017 & $\begin{array}{l}\text { Areas with evidence of equity and } \\
\text { their progress on mortality from } \\
\text { tuberculosis in an endemic } \\
\text { municipality of southeast Brazil }\end{array}$ & $\begin{array}{l}\text { Infectious Diseases of } \\
\text { Poverty }\end{array}$ & 2 \\
\hline Yang, H. B. et al. & 2018 & $\begin{array}{c}\text { Feedback of telecoupling: the case of a } \\
\text { payments for ecosystem services } \\
\text { program }\end{array}$ & Ecology and Society & 4 \\
\hline Yang, Y. C. E. & 2018 & $\begin{array}{l}\text { Gendered perspectives of ecosystem } \\
\text { services: A systematic review }\end{array}$ & Ecosystem Services & 17 \\
\hline
\end{tabular}

\subsection{Urban Green Infrastructure in the Literature}

The term "green infrastructure" (UGI) was in the largest cluster of "sustainable cities" and was connected to terms such as "climate change," "challenges," "heat island," "environmental benefits," and "socio-ecological resilience" (Figure 5 and Table 4). This was expected, as UGI in the form of rain gardens and wetlands bring multiple benefits to cities including flood mitigation [98], waterway health protection [99], microclimate improvement [100], and amenity values to urban landscapes [101]. Nonetheless, UGI studies were relatively limited, with only two studies using the term "Urban Green Infrastructure" in their titles. The review by du Toit et al. [102] found that sub-Saharan African cities lacked in-depth studies on UGI and ecosystem services and especially supporting and 
cultural services. Haruna et al. [103] also conducted a literature review and demonstrated how urban-planning strategies directed towards eco-aesthetics via UGI could assist cities to develop and maintain UGI in the long term by aligning local cultural practices and socio-economic preferences with sustainable processes. Three main limiting factors (i.e., a financial factor, lack of awareness, and land acquisition) were identified as barriers to achieve future development of a culture of eco-aesthetics in Ghana. Two studies discussed the topic of urban wetlands [88] and "nature-based solutions," [104] which are synonymous with GI. Wetlands and other UGI (such as rain gardens and bioswales) have been developed under the concepts of nature-based solutions, low-impact development, watersensitive urban design, and sponge cities and have received widespread attention in the past decades for sustainable urban-water management. Even though research on UGI, cities, and SDGs is growing $[50,105]$, there is a lack of research directly linking SDGs with UGI. Only a single study [104] proposed the use of nature-based solutions to restore urban natural ecosystems as a way to overcome urban water challenges across four sectors (i.e., cities, food production, hydropower, and flood protection).

\section{Discussion}

Having analysed current research on the SDGs, from the years 1997 to 2018 (see Figure 3) and the interrelationships between dominant knowledge clusters within this sample and having reviewed 66 relevant studies on the SDGs, ecosystem services, and cities we now consider the implications of our results for meeting the challenge of the SDGs through urban green infrastructure. Based on our assessment of the evolution of SDGs research (see Figure 3), it is evident that research on ecosystem services and the green infrastructure that delivers them is not developed enough to play a central role in addressing the SDGs through sustainable urban development, renewable-resource provision, and the cleaner production of urban services. This is a missed opportunity and concerning because based on current trajectories, the world will not achieve the 2030 agenda for sustainable development unless greater investment is made in sustainable transitions [15]. Studies such as those of Schewenius et al. [46], Ahern et al. [106], and Hansen et al. [107], undertaken prior to the formal launch of the SDGs, recommend improving links between urban planning and the provision of ecosystem services. However, more than five years on from these studies, our research clarifies that necessary research is not resulting in the production of a transdisciplinary scientific knowledge base that links urban green infrastructure to the 2030 sustainable agenda and the SDGs. This is evident from the lack of scientific literature that frames UGI in terms of achieving global programs such as the SDGs and the New Urban Agenda.

In the following discussion, we present our three main findings and subsequently conceptualise how a greater emphasis on transdisciplinarity, and urban green infrastructure research can change and improve the observed situation. Through reframing current infrastructure in terms of ecosystem services, urban systems can prevent the production of waste, whilst improving sustainability outcomes in the use of energy, water, material resources, and human wellbeing.

\subsection{The Evolving Knowledge Base of the SDGs, Cities, and Ecosystem Services}

Our first and foremost finding is that within SDGs research, urban ecosystem and UGI research is peripheral but nevertheless play a key role that can be enhanced through future strategic approaches. We found that ecosystem services are often considered in terms of conservation rather than as an element that needs to be integrated in a transformative way into future cleaner sustainable infrastructure. This positions the green and blue spaces of cities as a passive background rather in a more active foreground, that can shape future settlement patterns and service delivery. This is suggested in the three sets of analysis completed and presented in Figure 3 (time-based network analysis), Figure 4 (network analysis based on bibliographic coupling scores and cluster keywords), and Figure 5 (network analysis based on co-occurring search terms). 
In the coupling analysis (Figure 4), ecosystem services were featured in the various clusters in distinct ways. In cluster number 3, ecosystem services were considered predominantly in terms of the negative impact that cities have on ecosystems and framed in terms of necessary conservation approaches. Note the less well-developed and peripheral cluster number 1, which specifically considered ecosystem services as infrastructure that delivers services to the SDGs, and cluster 2, which is more central but considered ecosystem services more indirectly in the context of a variety of other topics. Cluster 4 had the lowest density but was the best positioned within the network map as it links the other three clusters. We can therefore classify ecosystem services in terms of the following four categories:

- $\quad$ Ecosystem services that contribute directly to SDGs (cluster 1).

- Ecosystem services that contribute indirectly to the SDGs (cluster 2).

- $\quad$ The impact of urbanisation on ecosystem services (cluster 3).

- Building resilience and sustainability infrastructure to enhance ecosystem services and SDGs more broadly (cluster 4).

Despite its lack of density, cluster 4 focused on building resilience and sustainability to enhance ecosystem services and SDGs more broadly, which are arguably the most important for building a holistic integrated approach for enhancing ecosystem services so they can deliver urban services necessary to achieve the SDGs. This interpretation supports recent research by Bush and Doyon [108] who argue that "Nature-based solutions directly address and contribute to increased urban resilience. However, implementing naturebased solutions is inherently complex, given the range of ecosystem services, their multifunctionality and the trade-offs between functions, and across temporal and spatial scales."

In Figure 5 (network analysis based on co-occurring search terms and mapping of the 10 major SDGs knowledge domains related to cities, SDGs, and urban ecosystems), the ecosystem clusters were also peripheral to the central cluster, which was sustainable cities. Cluster 3, focused on "ecosystem services," is located at the periphery of the overall term network ranking 11th in the network for betweenness centrality. However, it provides critical bridging ties to three significant clusters such as "climate change," "challenges," and "sustainable cities." So, whilst ecosystem services are yet to be integrated into central locations within SDGs knowledge domains, they nevertheless have a key role in addressing grand challenges of a global nature such as climate change and urbanisation [106,108,109].

In our mapping of the 10 major SDGs knowledge domains (Figure 5), it was evident that cluster 2 (challenges and ecosystem service) and cluster 3 (ecosystem service) are not supported by solution-based terms or phrases such as "infrastructure" or "achieving sustainable development goal" as can be identified in cluster 4 . The research terms that cluster 4 integrates included, amongst others, "achieving sustainable development goal; city; ecological footprint; human development index; poverty; sub-national level; environmental sustainability; environmental impacts; analytic hierarchy process;" which tend to be more solution- or process-focused rather than problem-focused as can be seen in cluster 2 and cluster 3 (framework; ecosystem services; land-use; challenges; impact; human well-being; governance; multiple ecosystem service; urban sprawl; urban expansion; ecosystem service; climate change; conservation; sustainability; indicators; health service; new urban agenda; urban sustainability; services; economic development).

Although there are a considerable amount of green-infrastructure policy and design approaches being applied in cities around the world [110-112], this practical work did not establish clear links to current research on ecosystem services in the context of the SDGs. The evolution of SDGs knowledge is clearly charted in Figure 2. Whilst this figure demonstrates the increasing integration of knowledge on the SDGs and the clear importance of cites to current research on the SDGs, the role of ecosystem services and green-infrastructure research is unclear.

However, there are exceptions. Abdalla et al. [113] and Mercedes Garcia et al. [114] discuss how innovative grey and black water systems using green infrastructure reduce resource use and provide better sanitation and water services. Urban green infrastructure approaches also can reduce the energy needed to transport and produce water, assist with 
the recovery of energy and resources, and even assist in the production of "clean" energy, thereby lessening pressures on natural resources and the ecosystems waste paradigm. Masi et al. [115] argues that cities need to adopt biogeochemical cycles, integrating a resourceoriented, circular economy and ecosystem-service considerations, and, in doing so, move beyond the current "waste" paradigm that dominates cities globally. Such ecosystemservice modes of service delivery however need to be tailored to local cultural and economic contexts. Further, Cetrulo et al. [116] highlighted that current SDGs approaches do not allow robust conclusions about inequality and accessibility of ecosystem services such as water. Urban development in rapidly urbanizing contexts can exacerbate inequality within cities [60], and this extends to ecosystem services, which are particularly important for vulnerable and poorer populations.

Finally, our temporal analysis of the literature on SDGs demonstrates that relevant knowledge networks have developed over time, but those related to ecosystem services and green infrastructure remain largely peripheral and require better integration within future research agendas. For example, the betweenness centrality of "urban greenspace" was "1," signalling its peripheral position and low ranking within the SDGs cluster. Further "urban ecology" had a betweenness centrality of "5," signalling its peripheral position and only slightly higher ranking than "urban green space" (Figure 3; Table 1). The temporal analysis therefore demonstrates the importance for urban green-infrastructure- and ecosystem-focused researchers to be cognisant of linking their work to central or anchor terms and themes (i.e., sustainability, resilience, economic growth, biodiversity, and climate change) but also to position their work in terms of mainstream infrastructure concepts to generate new more robust links to emerging concepts such as "climate change adaptation," "actionable knowledge," "rapid urbanisation," and "new urban agenda" and more mainstream concepts such as "health policy" and "well-being," where ecological and green infrastructure have considerable potential to contribute to as current research well supports $[20,57,106,117,118]$.

\subsection{The State of Research on Urban Green Infrastructure and the SDGs}

Our second finding concerns the lack of literature explicitly linking urban green infrastructure (UGI) and the many diverse areas of cities and the SDGs. Although Figure 5 shows a strong association between ecosystem services and climate change, there were weak linkages with other areas such as health, private property, and cities more generally. Our insights therefore complement research by authors such as Zinkernagel et al. [119] who have highlighted a need for more research on localizing the SDGs for specific urban targets. Considering the worldwide scale of urbanisation, innovative research is needed to support global sustainable governance and develop cleaner and more-sustainable infrastructure to achieve the 2030 Agenda for Sustainable Development and the SDGs. Urban green infrastructure (UGI) can deliver the ecosystem services necessary to achieve multiple SDGs [29] as it works in resourceful, multifunctional, synergistic, and environmentally sensitive ways to provide alternative cleaner pathways for the delivery of multiple urban services. Despite research by authors such as Johnson et al. [57], who show the usefulness and potential of urban ecosystem services for achieving multiple SDGs, our research demonstrates a lack of literature that demonstrates practical and applied approaches for delivering ecosystem services through green infrastructure to achieve the SDGs in innovative and synergistic ways necessary for the network-based structure of this global mechanism. This is critical because UGI is vital for delivering ecosystem services that are key to addressing so many of the SDG targets [49].

The lack of research on the application of UGI for the SDGs suggests that that research communities are not engaged with local, urban, or global agencies in advancing innovative green infrastructure solutions to serious pollution, climate, and resource problems. As Bhaduri et al. [59] points out with specific reference to water services, the SDGs generally are measured at a national level, and local and urban assessments on water risk assessment 
is needed as global-scale assessments may overlook them, masking distinctive local water challenges [61] and risks particular to the urban context.

Despite substantial and sophisticated bodies of work being undertaken at the local government level and in professional capacities [120,121], these generally have not been benchmarked against global mechanisms such as the SDGs. Even a cosmopolitan global city such as New York [122], which has a multiyear green-infrastructure-reporting mechanism, remains largely parochial in its lack of global benchmarking and links to critical global policies.

Although ecosystem services are relatively new as a scientific concept, the basic ecological principles that they emerge from have a long history in urban-planning and urban-sustainability initiatives. For example, eco-cities [123] have previously been put forward as an innovative way of better addressing urban-sustainability challenges around the world in locations as diverse as Europe, China, and Africa. They have been described as urban settlements that "minimises waste and pollution, maximises energy efficiency in buildings and transportation, utilises renewable energy and resources ... provides good-quality public spaces for citizens, and conserves valued features of the local ecology and landscape" [124]. Lin [123] defines ecocities as "an ecologically healthy city that enables residents to live a high-quality life with minimal impact on the environment, a goal tied to the notion of sustainability and broadly accepted across cultures." Perhaps Chang et al [125] offer the best and most-concise definition, emphasizing that eco-cities express the possibility of an urban future in which urban growth becomes compatible with ecological processes.

Although numerous urban areas have aspired to become eco-cities, settlements such as Singapore have long conserved water and forest systems to safeguard ecosystem services whilst also developing specialized metrics to monitor and understand the health and sustainability of the city [126]. Such historical examples provide important precedents for cities looking to achieve the SDGs through better conservation and design innovation with ecosystem services. Nevertheless, such exemplars are not always well linked to SDGs-urban-focused research. Scholars such as Zinkernagel et al. [119] suggest further research is needed to calibrate and adapt SDGs, targets, and indicators to cities and urban contexts. Knowledge exchange and transfer can be supported by linking and evaluating such existing ecosystem services and green-infrastructure initiatives [127] with the SDGs.

There are a number of important global policies that attempt to advance research and policy on ecosystem services relevant to cities and urban areas. These include the Cities and Biodiversity Outlook (CBO), which lays out the various ways biodiversity is significant to cities through ten guiding principles. In presenting messages for strengthening conservation and sustainable use of natural resources in an urban context, the CBO mentions green infrastructure in relation to a number of local government initiatives in cities such as Cape Town and Sao Paulo [128]. The CBO document also references and closely integrates a number of global policies such as The Economics of Ecosystems and Biodiversity (TEEB) and the Aichi targets, which are indispensable non-binding documents relevant to urban biodiversity conservation $[129,130]$.

There are significant barriers to harnessing urban-ecosystem-services research, including the multiscalar assessment of sustainability in a way that is relevant and measurable for cities [52]. To address this challenge, future research can emphasize data collection at the urban scale and can also ensure that national datasets can be disaggregated geographically to the urban scale $[131,132]$. This sensitivity to the urban can assist with measuring and understanding local performance and urban equity, whilst also facilitating the creation of appropriate benchmarks and appropriate targets for urban-sustainability indicators [133]. High-resolution datasets gathered from both remote sensing and IoT have the potential to help overcome such data-collection challenges [134,135].

There is an awareness amongst researchers that better linkages need to be established between policy and governance scales. Khoshkar et al. [136,137] highlight this in their recent study on enhancing ecosystem services within local or municipal planning. Although 
our research suggests that health and ecosystem services share weak linkages when it comes to SDGs research, there is an increasing awareness of the social and cultural importance of ecosystem services in cities research [138]. Such research needs to be better integrated into the SDGs knowledge networks to ensure that globally cities both benefit from ecosystem services and act to protect them.

\subsection{Addressing Critical Knowledge Gaps to Harness UGI to Meet the SDGs}

Our third major finding is that transdisciplinary knowledge explicitly relating to urban green infrastructure is missing from the current conversation on the SDGs. Based on our results, we make recommendations on how to change the observed situation in which knowledge is fragmented between ecosystem services, policy, and professional practice and to better support the SDGs through coherent socially relevant research on urban green infrastructure.

The central location of the term "cities" in the overall SDGs network (Figure 3f) demonstrates its significance in SDG research. However, as we explained in relation to our first finding, urban-focused research efforts presented by terms such as urban ecology, urban policy, and urban development within the Web of Science sample were peripheral rather than central. One reason is that urban research is not well focused on the city as a system that is intertwined with social and ecological systems [139]. Authors such as Childers et al. $[23,140]$ have advanced a "transformative model that merges urban design and ecology into an inclusive, creative, knowledge-to-action process," a significant contribution towards a more networked position that anchors urban-based knowledge amongst the other SDGs domains. Future GI must promote both traditional green spaces and urban ecological systems but must also work with a range of sectors across the SDGs to transform water, biodiversity, and food systems [29]. To create and advance such forms of action, scientists, designers, and urbanists will have to transform conventional ways of working to more open networked communication and collaborative models. Within academic institutions, conventional administrative and disciplinary silo structures fragment knowledge along disciplinary lines. Further promotional and tenure processes disincentivise transdisciplinary work, whilst faculty reward and funding processes promote disciplinary boundaries [141]. The results of our analysis demonstrate that while many knowledge clusters demonstrate strong multidisciplinarity (i.e., integrating several disciplines to address research questions), there is a lack of transdisciplinary studies focused on SDGs and urban GI. Such studies would seek to transform current urban planning, design, development, and management paradigms to enable and promote transdisciplinary urban solutions that elevate urban ecology as a foundation for future cities [24].

Our review of studies on the SDGs, ecosystem services, and UGI contained few paradigm-shifting studies of the kind needed to transform the current situation. Influential research such as that of McGranahan and Satterthwaite [96] advanced our understanding of urban and global systems and advocated for a more-inclusive and synthetic approach to urban sustainability. However, most studies in the sample focused within disciplinary silos rather than across urban sustainability and change. While these disciplinary studies provide useful and important information, there is a need for an increased quantum of research that explicitly links the delivery of urban ecosystems services to a greater diversity of disciplinary areas and approaches.

Various studies note the difficulty of embedding ecological paradigms in the anthropogenic perspective engendered by urban studies [142,143]. It is also apparent that it is difficult for ecologists to wrap their heads around "design" ways of thinking [144] and what Pohl et al. [145] characterize as the realm of practice, which is concerned with "what works" rather than "what is true," which is characteristic of scientific research. Current crossdisciplinary studies that advance emerging and new disciplines can be seen as a bridge to developing transdisciplinary approaches [146,147]. Transdisciplinarity was developed following international consensus on the Brundtland report [148] as an approach to transcend disciplinary boundaries and achieve global and environmental change. As an iterative and 
evolving method that draws upon a range of perspectives and developmental approaches, transdisciplinarity is necessary to integrate urban ecosystem services in mainstream urban studies. Studies such as that by Mann et al. [149] focus on multi-actor, multi-sector action, and collaboration to achieve superior outcomes in advancing SDG 11. Likewise, $\mathrm{Nel}$ et al. [27] and Ricciardelli et al. [150] focused on collaboration to achieve water security and disaster resilience. To facilitate genuine society-based collaboration, transdisciplinary research promotes stakeholder engagement with experts and communities [151-153]. Bernstein [154] and Wickson and Carew [155], promote such transdisciplinary practice through stakeholder engagement and collaboration techniques. In the term-based bibliographic analysis (Figure 4), the orange cluster on urbanisation integrated a range of action-based and transdisciplinary terms such as "bottom-up approach," "global unrest," "global coalition," "broad multilateral agreement," and "innovative future vision." This cluster must be further developed to interact with other domain clusters to foster transdisciplinarity. To harness UGI to address urban-sustainability research, transdisciplinary team-building needs to be seen as a wicked problem all of its own [156].

Currently, multiple SDGs can be addressed by urban green infrastructure (UGI), but these are usually addressed in a fragmentary and isolated way. For example, ecosystem services may be considered in isolation in terms of metrics, but how these can be produced or enhanced and used to address multiple urban problems and challenges is rarely considered in combination and in a holistic way. By bringing together experts with multiple ways of seeing, understanding, handling, and working to resolve problems, the network-based nature of UGI can be leveraged to address the distance between those who understand and measure ecosystem services and those who envision and build urban green infrastructure. Further, the complex interactions between the SDGs are very difficult to understand and address in everyday practice, especially when dealing with emerging knowledge domains such as urban ecosystem services and through urban green infrastructure. Transdisciplinary approaches such as that proposed by Figure 6 can help to integrate and address the various cross-system challenges presented by the SDGs.

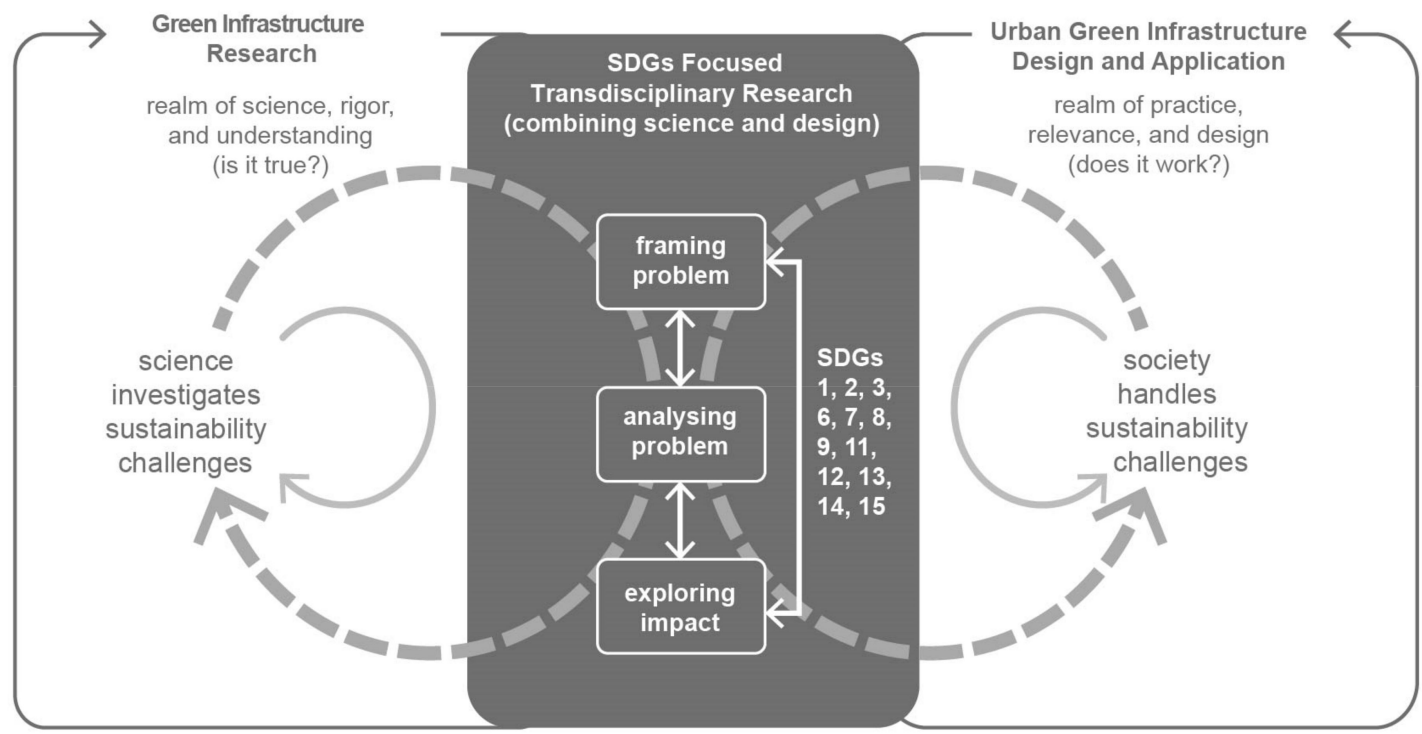

Figure 6. This diagram, adapted from Pohl et al. [145]; Hoffmann et al. [157]; and Lang et al. [158], visualises and clarifies the separation between "scientific knowledge production and societal problem handling" [145] and how the strengths of each maybe leveraged to better address the SDGs. Current knowledge production is largely typified by the smaller circular arrows representing science or society defining and addressing its own set of problems and/or questions. To develop research that integrates both the definitions and understanding of the urban ecosystems and their integration and enhancement to address societal problems, the larger, circular, dashed arrows that integrate both stakeholder groups in the process of transdisciplinary research necessary for addressing the SDGs grand challenges need to be followed. By bringing together both the scientific and design ways of thinking for working on SDGs and UGI -focused research, a broad cross-section of SDGs can be addressed (SDGS 1, 2, 3, 6, 7, 8, 9, 11, 12, 13, 14, and 15 identified by Wood et al., 2019). 
There is a lack of clarity about how ecosystem services contribute to urban needs and outcomes. Hansen et al. [110] state that the scepticisms of some "practitioners have to be considered, and research needs to provide proof of the validity and added value of ES approaches." Transdisciplinary approaches can strengthen holistic perspectives and the links between research on ecosystem services, UGI, and urban nature and its manifold contributions to the SDGs. Such research can identify additional benefits from the environment not usually considered in the practical approaches of professionals and local governments. By bringing stakeholders together to further transdisciplinary research, green infrastructure has a better chance of overcoming existing barriers to address the formidable range of problems that have been identified as being suitable targets for such approaches [49,57,63,158-160]. As Pohl et al. [145] state, the "challenge of a td (transdisciplinary) research process is to provide links between 'science' and 'practice.'"

In relation to this last finding, of the separation between practical applied knowledge on UGI and other urban and ecosystem knowledge domains, it is evident that continued development of urban science and design domains and ways of working is needed so they can function as "knowledge networks." Advocacy for these ways of working is required from both research scientists and those engaged as design professionals. Researchers can increase the relevance and impact of their research by collaborating with professionals in implementing and planning future cities and GI. Current transdisciplinary knowledge suggests multiple ways to facilitate this; however, we found the clearest and most practical exposition of the transdisciplinary approach in the work of Pohl et al. $[145,160]$ as introduced above (Figure 6). Pohl et al. [145] recommend a clear process that brings together multiple steps under three stages. These are firstly matching research questions with societal knowledge demand, secondly identifying relevant researchers, professionals, communities, and governments and planning how to support collaboration between these stakeholders, and finally reflecting about the impact and the process after projects have been implemented through a regular reporting process [145].

What is clear is that mainstreaming peripheral urban systems and approaches characteristic of UGI will require innovative and sometimes unconventional approaches very different to those used to deliver the monofunctional grey infrastructure currently used to deliver and structure many of the current services in cities. A softer, more-reflexive approach drawing on a wider range of expertise, disciplines, and processes will be required to envision and implement the UGI necessary to transform our cities so that they may meet the 2030 sustainable development agenda.

\section{Conclusions}

In this study, a critical and systematic literature search on the SDGs, urban ecosystem services, and UGI revealed a critical knowledge gap on how ecosystem services can help cities achieve the SDGs. To assess current research on the SDGs and linkages between UGI and the SDGs, we analysed 3392 studies on the SDGs in the WoS database and reviewed 66 of those with relevance to ecosystem services and urban research. We used analytic approaches from network science to understand the relationship of different clusters of SDGs research from 2010 to 2018 across disciplines and in relation to urban green infrastructure.

We found that research on the SDGs has developed stronger networks over time but that not all networks on knowledge domains were well integrated with research on the SDGs. For example, whilst research on "cities" now occupies a central place in the SDGs literature, sustainable and cleaner production topics such as urban green infrastructure remain largely unaddressed and peripheral. Of the 66 studies that addressed urban-ecosystem services, only two considered urban green infrastructure for delivering ecosystem services to achieve the SDGs. Available knowledge on UGI tends to be fragmented and focuses on specific urban challenges rather than on addressing the rapid systemic change needed to achieve the 2030 UN agenda. 
We conclude that when it comes to the SDGs, ecosystem services are largely considered independently of the UGI that delivers them. This has serious implications. UGI is the network that sustains the provision of ecosystem services. If policymakers, practitioners, and researchers do not recognise, or develop, UGI through evidence-based research, cities may struggle to strengthen urban ecosystems to deliver the increased quantity of sustainable services necessary to meet growing cities and the large urban populations of tomorrow. Current infrastructure developed in today's rapidly urbanising environments will also miss out on evidence-based decision-making necessary to align future development with global sustainability targets. Further and more generally, it suggests that researchers and policymakers are not considering UGI enough as a viable and sustainable alternative to conventional urban infrastructures. To address these shortcomings, we recommend that transdisciplinary research is more vigorously promoted and applied to research, to ensure urban developmental pathways consider the potential of urban green infrastructure to contribute to the 2030 global sustainability agenda. Transdisciplinarity offers a framework to structure interactions between scientists, design professionals, and urban governments so that research is socially relevant and so that infrastructure is based upon solid sustainability science and cleaner production principles. Ensuring such solution-based approaches are successful will take considerably more research. Ominously, our temporal analysis of the Web of Science database found that the annual production of research literature on the SDGs decreased in 2018. This occurred despite there being major challenges and research gaps that remain.

To address this knowledge gap, this study argues for scientists, designers, planners, and all those involved in the production of urban knowledge and GI to engage with the SDGs and design research projects that provide connections with new areas of SDG knowledge. Such trends and lacunae need to be urgently addressed through renewed transdisciplinary research efforts.

Our study is, of course, limited to the WoS database, but this comprehensive global scientific resource is a strong indicator of current trends. We looked beyond this resource to guide our discussion and insights into urban green infrastructure, and it is evident that professional and government grey literature provides insights on the practical application of UGI to urban environments. In general, we found that these two sources of knowledge are lacking through their fragmentation and isolation. Despite focused interest in green spaces and green infrastructure around the world, how this resource can be expanded and applied to a range of formidable problems specifically posed by the SDGs remains largely unaddressed. These two ways of thinking, the scientific and the design based, need to be more closely linked through transdisciplinary approaches to generate a better understanding of solution and evidence-based strategies for delivering the SDGs. Promisingly, clusters of knowledge promoting transdisciplinarity have emerged. Approaches such as co-design, collaboration, stakeholder engagement, and community knowledge can promote transdisciplinarity across science and design disciplines. These approaches need to be better promoted and adopted by these stakeholder groups. Such approaches distribute transformation across and between the knowledge silos that urban infrastructure is currently delivered within. Specifically, this study argues for scientists, designers, planners, and all those involved in the production of urban knowledge and UGI to engage with the SDGs and design research projects that generate connections with new areas of SDG knowledge.

Author Contributions: Conceptualization, S.H. and H.R.; methodology, S.H., H.R., S.M.E.S. and K.Z; software, H.R.; validation, S.H.; formal analysis, S.H., H.R. and K.Z.; investigation, S.H. and K.Z.; resources, S.H.; data curation, H.R.; writing—original draft preparation, S.H., H.R. and K.Z.; writingreview and editing, S.H.; visualization, H.R. and S.H.; supervision, S.H.; project administration, S.H.; funding acquisition, S.H. and S.M.E.S. All authors have read and agreed to the published version of the manuscript.

Funding: This research was funded through the UNSW Sydney Cross Faculty Lab for Urban Water Resilience funding number RG182531. 
Institutional Review Board Statement: Not applicable.

Informed Consent Statement: Not applicable.

Data Availability Statement: Not applicable.

Conflicts of Interest: The authors declare no conflict of interest.

\section{References}

1. Colglazier, W. Sustainable Development Agenda: 2030. Science 2015, 349, 1048-1050. [CrossRef] [PubMed]

2. Hidalgo, D. Cities and Human Settlements in the Development Agenda. SAIS Rev. Int. Aff. 2014, 34, 63-81. [CrossRef]

3. United Nations World Urbanization Prospects-Population Division-United Nations. Available online: http://esa.un.org/ unpd/wup/DataQuery/ (accessed on 11 January 2016).

4. UN-Habitat. State of African Cities 2014: Re-Imagining Sustainable Urban. Transitions; UN-Habitat: Nairobi, Kenya, 2015.

5. UN-Habitat. The State of Asian Cities 2010/11; UN-Habitat: Fukuoka, Japan, 2010.

6. Dovey, K. Informal Urbanism and Complex Adaptive Assemblage. Int. Dev. Plan. Rev. 2012, 34, 349-367. [CrossRef]

7. Gouverneur, D. Planning and Design for Future Informal Settlements: Shaping the Self-Constructed City; Routledge: Abingdon, UK; New York, NY, USA, 2014; ISBN 1-315-76593-4.

8. Montgomery, M.; Balk, D. The Urban Transition in Developing Countries: Demography Meets Geography. In Global urbanization; Birch, E.L., Wachter, S.M., Eds.; University of Pennsylvania Press: Philadelphia, PA, USA, 2011; pp. 89-106. ISBN 978-0-8122-4284-3.

9. Dovey, K. Incremental Urbanism: The Emergence of Informal Settlements. In Emergent Urbanism; Routledge: Abingdon, UK; New York, NY, USA, 2016; pp. 61-70.

10. Kamalipour, H.; Dovey, K. Mapping the Visibility of Informal Settlements. Habitat Int. 2019, 85, 63-75. [CrossRef]

11. Parker, S. The Majority Urban World: The Growth and Development of Cities in the Global South. In Urban Theory and the Urban Experience; Routledge: Abingdon, UK; New York, NY, USA, 2015; pp. 183-204.

12. Sirakaya, A.; Cliquet, A.; Harris, J. Ecosystem Services in Cities: Towards the International Legal Protection of Ecosystem Services in Urban Environments. Ecosyst. Serv. 2018, 29, 205-212. [CrossRef]

13. Kanuri, C.; Revi, A.; Espey, J.; Kuhle, H. Getting Started with the SDGs in Cities: A Guide for Stakeholders; United Nations Sustainable Development Solutions Network: New York, NY, USA; Paris, France, 2016.

14. United Nations. A New Global Partnership: Eradicate Poverty and Transform. Economies through Sustainable Development; United Nations: New York, NY, USA, 2013.

15. Independent Group of Scientists appointed by the Secretary-General. In Global Sustainable Development Report 2019: The Future Is Now: Science for Achieving Sustainable Development; United Nations: New York, NY, USA, 2019.

16. Millennium Ecosystem Assessment. In Living beyond Our Means: Natural Assets and Human Well-Being; Millennium Ecosystem Assessment: Washington, DC, USA, 2005.

17. Kennedy, C.; Corfee-Morlot, J. Past Performance and Future Needs for Low Carbon Climate Resilient Infrastructure-An Investment Perspective. Energy Policy 2013, 59, 773-783. [CrossRef]

18. Li, F.; Liu, H.X.; Huisingh, D.; Wang, Y.T.; Wang, R.S. Shifting to Healthier Cities with Improved Urban Ecological Infrastructure: From the Perspectives of Planning, Implementation, Governance and Engineering. J. Clean. Prod. 2017, 163, S1-S11. [CrossRef]

19. Zhang, X.L.; Hes, D.; Wu, Y.Z.; Hafkamp, W.; Lu, W.S.; Bayulken, B.; Schnitzer, H.; Li, F. Catalyzing Sustainable Urban Transformations towards Smarter, Healthier Cities through Urban Ecological Infrastructure, Regenerative Development, Eco Towns and Regional Prosperity. J. Clean. Prod. 2016, 122, 2-4. [CrossRef]

20. Hansen, R.; Olafsson, A.S.; van der Jagt, A.P.N.; Rall, E.; Pauleit, S. Planning Multifunctional Green Infrastructure for Compact Cities: What Is the State of Practice? Ecol. Indic. 2019, 96, 99-110. [CrossRef]

21. Childers, D.L.; Bois, P.; Hartnett, H.E.; McPhearson, T.; Metson, G.S.; Sanchez, C.A. Urban Ecological Infrastructure: An Inclusive Concept for the Non-Built Urban Environment. Elem. Sci. Anthr. 2019, 7, 46. [CrossRef]

22. Ahern, J. Urban Landscape Sustainability and Resilience: The Promise and Challenges of Integrating Ecology with Urban Planning and Design. Landsc. Ecol. 2013, 28, 1203-1212. [CrossRef]

23. Childers, D.L.; Cadenasso, M.L.; Morgan Grove, J.; Marshall, V.; McGrath, B.; Pickett, S.T.A. An Ecology for Cities: A Transformational Nexus of Design and Ecology to Advance Climate Change Resilience and Urban Sustainability. Sustainability 2015, 7, 3774-3791. [CrossRef]

24. Andersson, E.; Barthel, S.; Borgström, S.; Colding, J.; Elmqvist, T.; Folke, C.; Gren, Å. Reconnecting Cities to the Biosphere: Stewardship of Green Infrastructure and Urban Ecosystem Services. AMBIO 2014, 43, 445-453. [CrossRef]

25. Costanza, R.; d'Arge, R.; de Groot, R.; Farber, S.; Grasso, M.; Hannon, B.; Limburg, K.; Naeem, S.; O’Neill, R.V.; Paruelo, J.; et al. The Value of the World's Ecosystem Services and Natural Capital. Nature 1997, 387, 253-260. [CrossRef]

26. Crossman, N.D.; Burkhard, B.; Nedkov, S.; Willemen, L.; Petz, K.; Palomo, I.; Drakou, E.G.; Martín-Lopez, B.; McPhearson, T.; Boyanova, K.; et al. A Blueprint for Mapping and Modelling Ecosystem Services. Ecosyst. Serv. 2013, 4, 4-14. [CrossRef]

27. Nel, J.L.; Le Maitre, D.C.; Roux, D.J.; Colvin, C.; Smith, J.S.; Smith-Adao, L.B.; Maherry, A.; Sitas, N. Strategic Water Source Areas for Urban Water Security: Making the Connection between Protecting Ecosystems and Benefiting from Their Services. Ecosyst. Serv. 2017, 28, 251-259. [CrossRef] 
28. Breuste, J.; Haase, D.; Elmqvist, T. Urban Landscapes and Ecosystem Services. In Ecosystem Services in Agricultural and Urban Landscapes; John Wiley and Sons Ltd.: Chicester, UK, 2013; pp. 83-104. [CrossRef]

29. Wood, S.; Jones, S.; Johnson, J.; Brauman, K.A.; Chaplin-Kramer, R.; Fremier, A.; Girvetz, E.; Gordon, L.J.; Kappel, C.V.; Mandle, L.; et al. Distilling the Role of Ecosystem Services in the Sustainable Development Goals. Ecosyst. Serv. 2018, 29, 70-82. [CrossRef]

30. Wood, S.L.; DeClerck, F. Ecosystems and Human Well-Being in the Sustainable Development Goals. Front. Ecol. Environ. 2015, 13, 123. [CrossRef]

31. Yang, S.; Zhao, W.; Liu, Y.; Cherubini, F.; Fu, B.; Pereira, P. Prioritizing Sustainable Development Goals and Linking Them to Ecosystem Services: A Global Expert's Knowledge Evaluation. Geogr. Sustain. 2020, 1, 321-330. [CrossRef]

32. Cumming, T.L.; Shackleton, R.T.; Förster, J.; Dini, J.; Khan, A.; Gumula, M.; Kubiszewski, I. Achieving the National Development Agenda and the Sustainable Development Goals (SDGs) through Investment in Ecological Infrastructure: A Case Study of South Africa. Ecosyst. Serv. 2017, 27, 253-260. [CrossRef]

33. Chen, D.; Zhao, Q.; Jiang, P.; Li, M. Incorporating Ecosystem Services to Assess Progress towards Sustainable Development Goals: A Case Study of the Yangtze River Economic Belt, China. Sci. Total Environ. 2022, 806, 151277. [CrossRef]

34. Benedict, M.A.; McMahon, E.T.; Fund, M.A.T.C. Green Infrastructure: Linking Landscapes and Communities; Island Press: Washington, DC, USA, 2012; ISBN 978-1-59726-764-9.

35. Fletcher, T.D.; Shuster, W.; Hunt, W.F.; Ashley, R.; Butler, D.; Arthur, S.; Trowsdale, S.; Barraud, S.; Semadeni-Davies, A.; BertrandKrajewski, J.-L.; et al. SUDS, LID, BMPs, WSUD and More-The Evolution and Application of Terminology Surrounding Urban Drainage. Urban Water J. 2015, 12, 525-542. [CrossRef]

36. Bartesaghi Koc, C.; Osmond, P.; Peters, A. Towards a Comprehensive Green Infrastructure Typology: A Systematic Review of Approaches, Methods and Typologies. Urban Ecosyst. 2017, 20, 15-35. [CrossRef]

37. Da Silva, J.M.C.; Wheeler, E. Ecosystems as Infrastructure. Perspect. Ecol. Conserv. 2017, 15, 32-35. [CrossRef]

38. Pincetl, S. Cities as Novel Biomes: Recognizing Urban Ecosystem Services as Anthropogenic. Front. Ecol. Evol. 2015, 3, 140. [CrossRef]

39. Abson, D.J.; Fischer, J.; Leventon, J.; Newig, J.; Schomerus, T.; Vilsmaier, U.; von Wehrden, H.; Abernethy, P.; Ives, C.D.; Jager, N.W. Leverage Points for Sustainability Transformation. AMBIO 2017, 46, 30-39. [CrossRef]

40. Derrible, S. Urban Infrastructure Is Not a Tree: Integrating and Decentralizing Urban Infrastructure Systems. Environ. Plan. B Urban Anal. City Sci. 2017, 44, 553-569. [CrossRef]

41. Kati, V.; Jari, N. Bottom-up Thinking-Identifying Socio-Cultural Values of Ecosystem Services in Local Blue-Green Infrastructure Planning in Helsinki, Finland. Land Use Policy 2016, 50, 537-547. [CrossRef]

42. Marissa Matsler, A. Making 'Green' Fit in a 'Grey' Accounting System: The Institutional Knowledge System Challenges of Valuing Urban Nature as Infrastructural Assets. Environ. Sci. Policy 2019, 99, 160-168. [CrossRef]

43. Musacchio, L.R.; Wu, J. Collaborative Landscape-Scale Ecological Research: Emerging Trends in Urban and Regional Ecology. Urban Ecosyst. 2004, 7, 175-178. [CrossRef]

44. Tidball, K.G.; Krasny, M.E. From Risk to Resilience: What Role for Community Greening and Civic Ecology in Cities. In Social Learning towards a Sustainable World; Wageningen Academic Publishers: Wageningen, The Netherlands, 2007; pp. 149-164. ISBN 9789086865949. [CrossRef]

45. Wolfram, M.; Frantzeskaki, N.; Maschmeyer, S. Cities, Systems and Sustainability: Status and Perspectives of Research on Urban Transformations. Curr. Opin. Environ. Sustain. 2016, 22, 18-25. [CrossRef]

46. Schewenius, M.; McPhearson, T.; Elmqvist, T. Opportunities for Increasing Resilience and Sustainability of Urban SocialEcological Systems: Insights from the URBES and the Cities and Biodiversity Outlook Projects. AMBIO 2014, 43, 434-444. [CrossRef] [PubMed]

47. Escobedo, F.J.; Giannico, V.; Jim, C.Y.; Sanesi, G.; Lafortezza, R. Urban Forests, Ecosystem Services, Green Infrastructure and Nature-Based Solutions: Nexus or Evolving Metaphors. Urban For. Urban Green. 2019, 37, 3-12. [CrossRef]

48. Maes, J.; Egoh, B.; Willemen, L.; Liquete, C.; Vihervaara, P.; Schägner, J.P.; Grizzetti, B.; Drakou, E.G.; Notte, A.L.; Zulian, G.; et al. Mapping Ecosystem Services for Policy Support and Decision Making in the European Union. Ecosyst. Serv. 2012, 1, 31-39. [CrossRef]

49. Maes, M.J.A.; Jones, K.E.; Toledano, M.B.; Milligan, B. Mapping Synergies and Trade-Offs between Urban Ecosystems and the Sustainable Development Goals. Environ. Sci. Policy 2019, 93, 181-188. [CrossRef]

50. Sørup, H.J.D.; Fryd, O.; Liu, L.; Arnbjerg-Nielsen, K.; Jensen, M.B. An SDG-Based Framework for Assessing Urban Stormwater Management Systems. Blue-Green Syst. 2019, 1, 102-118. [CrossRef]

51. Caprioli, C.; Oppio, A.; Baldassarre, R.; Grassi, R.; Dell’Ovo, M. A Multidimensional Assessment of Ecosystem Services: From Grey to Green Infrastructure. In Computational Science and Its Applications_ICCSA 2021; Gervasi, O., Murgante, B., Misra, S., Garau, C., Blečić, I., Taniar, D., Apduhan, B.O., Rocha, A.M.A.C., Tarantino, E., Torre, C.M., Eds.; Springer International Publishing: Cham, Switzerland, 2021; pp. 569-581.

52. Tan, P.Y.; Zhang, J.; Masoudi, M.; Alemu, J.B.; Edwards, P.J.; Grêt-Regamey, A.; Richards, D.R.; Saunders, J.; Song, X.P.; Wong, L.W. A Conceptual Framework to Untangle the Concept of Urban Ecosystem Services. Landsc. Urban Plan. 2020, $200,103837$. [CrossRef]

53. Yuan, M.-H.; Lo, S.-L. Ecosystem Services and Sustainable Development: Perspectives F1 Rom the Food-Energy-Water Nexus. Ecosyst. Serv. 2020, 46, 101217. [CrossRef] 
54. Benyus, J.M. Biomimicry: Innovation Inspired by Nature; Harper Perennial: New York, NY, USA, 2002; ISBN 0-06-053322-6.

55. Buck, N.T. The Art of Imitating Life: The Potential Contribution of Biomimicry in Shaping the Future of Our Cities. Environ. Plan. B Plan. Des. 2017, 44, 120-140. [CrossRef]

56. Pedersen Zari, M. Ecosystem Processes for Biomimetic Architectural and Urban Design. Archit. Sci. Rev. 2015, 58, 106-119. [CrossRef]

57. Johnson, J.A.; Jones, S.K.; Wood, S.L.; Chaplin-Kramer, R.; Hawthorne, P.L.; Mulligan, M.; Pennington, D.; DeClerck, F.A. Mapping Ecosystem Services to Human Well-Being: A Toolkit to Support Integrated Landscape Management for the SDGs. Ecol. Appl. 2019, 29, e01985. [CrossRef] [PubMed]

58. Adeoti, O.; Fati, B.O. Barriers to Extending Piped Water Distribution Networks: The Case of Ekiti State, Nigeria. Util. Policy 2020, 63, 100983. [CrossRef]

59. Bhaduri, A.; Bogardi, J.; Siddiqi, A.; Voigt, H.; Vörösmarty, C.; Pahl-Wostl, C.; Bunn, S.E.; Shrivastava, P.; Lawford, R.; Foster, S.; et al. Achieving Sustainable Development Goals from a Water Perspective. Front. Environ. Sci. 2016, 4, 64. [CrossRef]

60. Hawken, S.; Avazpour, B.; Harris, M.S.; Marzban, A.; Munro, P.G. Urban Megaprojects and Water Justice in Southeast Asia: Between Global Economies and Community Transitions. Cities 2021, 113, 103068. [CrossRef]

61. Hawken, S.; Sepasgozar, S.M.E.; Prodanovic, V.; Jing, J.; Bakelmun, A.; Avazpour, B.; Che, S.; Zhang, K. What Makes a Successful Sponge City Project? Expert Perceptions of Critical Factors in Integrated Urban Water Management in the Asia-Pacific. Sustain. Cities Soc. 2021, 75, 103317. [CrossRef]

62. Chung, M.G.; Frank, K.A.; Pokhrel, Y.; Dietz, T.; Liu, J. Natural Infrastructure in Sustaining Global Urban Freshwater Ecosystem Services. Nat. Sustain. 2021, 4, 1068-1075. [CrossRef]

63. Vörösmarty, C.J.; Osuna, V.R.; Cak, A.D.; Bhaduri, A.; Bunn, S.E.; Corsi, F.; Gastelumendi, J.; Green, P.; Harrison, I.; Lawford, R. Ecosystem-Based Water Security and the Sustainable Development Goals (SDGs). Ecohydrol. Hydrobiol. 2018, 18, 317-333. [CrossRef]

64. Picchi, P.; van Lierop, M.; Geneletti, D.; Stremke, S. Advancing the Relationship between Renewable Energy and Ecosystem Services for Landscape Planning and Design: A Literature Review. Ecosyst. Serv. 2019, 35, 241-259. [CrossRef]

65. Van den Heuvel, L.; Blicharska, M.; Masia, S.; Sušnik, J.; Teutschbein, C. Ecosystem Services in the Swedish Water-Energy-FoodLand-Climate Nexus: Anthropogenic Pressures and Physical Interactions. Ecosyst. Serv. 2020, 44, 101141. [CrossRef]

66. Messerli, P.; Kim, E.M.; Lutz, W.; Moatti, J.-P.; Richardson, K.; Saidam, M.; Smith, D.; Eloundou-Enyegue, P.; Foli, E.; Glassman, A.; et al. Expansion of Sustainability Science Needed for the SDGs. Nat. Sustain. 2019, 2, 892-894. [CrossRef]

67. Morales-Zapata, D.; Valencia-Arias, A.; Garcés-Giraldo, L.F.; Toro-Vanegas, E.; Quiroz-Fabra, J. Trends in Research Around the Sustainable Development Objectives: A Bibliometric Analysis. In Sustainable Development Goals for Society Vol. 1: Selected Topics of Global Relevance; Nhamo, G., Togo, M., Dube, K., Eds.; Sustainable Development Goals Series; Springer International Publishing: Cham, Switzerland, 2021; pp. 247-260. ISBN 978-3-030-70948-8.

68. Sweileh, W.M. Bibliometric Analysis of Scientific Publications on "Sustainable Development Goals" with Emphasis on "Good Health and Well-Being" Goal (2015-2019). Glob. Health 2020, 16, 68. [CrossRef] [PubMed]

69. Wang, M.-H.; Ho, Y.-S.; Fu, H.-Z. Global Performance and Development on Sustainable City Based on Natural Science and Social Science Research: A Bibliometric Analysis. Sci. Total Environ. 2019, 666, 1245-1254. [CrossRef] [PubMed]

70. Resilience and Complexity: A Bibliometric Review and Prospects for Industrial Ecology—Meerow-2015—Journal of Industrial Ecology_Wiley Online Library. Available online: http:// onlinelibrary.wiley.com/doi/10.1111/jiec.12252/full (accessed on 15 August 2016).

71. Droste, N.; D'Amato, D.; Goddard, J.J. Where Communities Intermingle, Diversity Grows-The Evolution of Topics in Ecosystem Service Research. PLoS ONE 2018, 13, e0204749. [CrossRef]

72. Meuleman, L.; Niestroy, I. Common but Differentiated Governance: A Metagovernance Approach to Make the SDGs Work. Sustainability 2015, 7, 12295-12321. [CrossRef]

73. Le Blanc, D. Towards Integration at Last? The Sustainable Development Goals as a Network of Targets. Sustain. Dev. 2015, 23, 176-187. [CrossRef]

74. Meschede, C. The Sustainable Development Goals in Scientific Literature: A Bibliometric Overview at the Meta-Level. Sustainability 2020, 12, 4461. [CrossRef]

75. Herrera-Calderon, O.; Yuli-Posadas, R.Á.; Peña-Rojas, G.; Andía-Ayme, V.; Hañari-Quispe, R.D.; Gregorio-Chaviano, O. A Bibliometric Analysis of the Scientific Production Related to "Zero Hunger" as a Sustainable Development Goal: Trends of the Pacific Alliance towards 2030. Agric. Food Secur. 2021, 10, 34. [CrossRef]

76. Web of Science Core Collection. Available online: https://clarivate.com/webofsciencegroup/solutions/web-of-science-corecollection/ (accessed on 4 December 2019).

77. Broadus, R.N. Toward a Definition of "Bibliometrics". Scientometrics 1987, 12, 373-379. [CrossRef]

78. Barabási, A.-L. Linked: The New Science of Networks; Perseus: Cambridge, MA, USA, 2002; ISBN 978-0-7382-0667-7.

79. Capra, F.; Luisi, P.L. The Systems View of Life: A Unifying Vision; Cambridge University Press: Cambridge, MA, USA, 2014; ISBN 978-1-107-01136-6.

80. Chen, C. The CiteSpace Manual Version 0.65; College of Computing and Informatics, Drexel University: Philadelphia, PA, USA, 2014.

81. Burt, R.S. Structural Holes: The Social Structure of Competition; Harvard University Press: Cambridge, MA, USA, 2009.

82. Kessler, M.M. Bibliographic Coupling between Scientific Papers. Am. Doc. 1963, 14, 10-25. [CrossRef] 
83. Bastian, M.; Heymann, S.; Jacomy, M. Gephi: An Open Source Software for Exploring and Manipulating Networks. ICWSM 2009, $8,361-362$

84. Fortunato, S. Community Detection in Graphs. Phys. Rep. 2010, 486, 75-174. [CrossRef]

85. Wasserman, S.; Faust, K. Social Network Analysis: Methods and Applications; Cambridge University Press: Cambridge, MA, USA, 1994.

86. Satterthwaite, D. Sustainable Cities or Cities That Contribute to Sustainable Development? Urban Stud. 1997, 34, 1667-1691. [CrossRef]

87. Andersson, K.; Dickin, S.; Rosemarin, A. Towards "Sustainable" Sanitation: Challenges and Opportunities in Urban Areas. Sustainability 2016, 8, 1289. [CrossRef]

88. Mao, D.H.; Wang, Z.M.; Wu, J.G.; Wu, B.F.; Zeng, Y.; Song, K.S.; Yi, K.P.; Luo, L. China's Wetlands Loss to Urban Expansion. Land Degrad. Dev. 2018, 29, 2644-2657. [CrossRef]

89. Sotoudeh, A.; Parivar, P. Applying Resilience Thinking to Select More Sustainable Urban Development Scenarios in Shiraz, Iran. Sci. Iran. 2016, 23, 1975-1983. [CrossRef]

90. Andrewin, A.N.; Rodriguez-Llanes, J.M.; Guha-Sapir, D. Determinants of the Lethality of Climate-Related Disasters in the Caribbean Community (CARICOM): A Cross-Country Analysis. Sci. Rep. 2015, 5, 11972. [CrossRef]

91. Beatriz, E.D.; Molnar, B.E.; Griffith, J.L.; Salhi, C. Urban-Rural Disparity and Urban Population Growth: A Multilevel Analysis of under-5 Mortality in 30 Sub-Saharan African Countries. Health Place 2018, 52, 196-204. [CrossRef] [PubMed]

92. Sheth, S.; IEEE. The TripleRM Global Health Management Model (GHMM): Strategic Risk Management of Vector Borne Infectious Diseases to Build Healthy, Sustainable, Adaptable and Resilient Communities (Strategic Global Health Security Risk Assessment, Resilience Planning And Resource Management in Urban and Rural Environments). In Proceedings of the 2017 IEEE Conference on Technologies for Sustainability, Phoenix, AZ, USA, 12-14 November 2017; pp. 310-316, ISBN 978-1-5386-0452-6.

93. Kharazian, P. Assessment of Geo-Tourism Structure in Bojnoord City Sustainable Tourism Development. Eur. J. Sustain. Dev. 2015, 4, 175-184. [CrossRef]

94. Musa, H.D.; Yacob, M.R.; Abdullah, A.M.; Ishak, M.Y. Enhancing Subjective Well-Being through Strategic Urban Planning: Development and Application of Community Happiness Index. Sustain. Cities Soc. 2018, 38, 184-194. [CrossRef]

95. Bibri, S.E.; Krogstie, J. Smart Sustainable Cities of the Future: An Extensive Interdisciplinary Literature Review. Sustain. Cities Soc. 2017, 31, 183-212. [CrossRef]

96. McGranahan, G.; Satterthwaite, D. Urban Centers: An Assessment of Sustainability. Annu. Rev. Environ. Resour. 2003, 28, 243-274. [CrossRef]

97. Kaika, M. ‘Don't Call Me Resilient Again!': The New Urban Agenda as Immunology ... or ... What Happens When Communities Refuse to Be Vaccinated with 'smart Cities' and Indicators. Environ. Urban 2017, 29, 89-102. [CrossRef]

98. Zhang, K.; Manuelpillai, D.; Raut, B.; Deletic, A.; Bach, P.M. Evaluating the Reliability of Stormwater Treatment Systems under Various Future Climate Conditions. J. Hydrol. 2019, 568, 57-66. [CrossRef]

99. Fletcher, T.D.; Mitchell, V.G.; Deletic, A.; Ladson, T.R.; Seven, A. Is Stormwater Harvesting Beneficial to Urban Waterway Environmental Flows? Water Sci. Technol. 2007, 55, 265-272. [CrossRef]

100. Wong, T.H.F.; Allen, R.A.; Brown, R.R.; Deletic, A.; Gangadharan, L.; Gernjak, W.; Jakob, C.; Reeder, M.J.; Tapper, N.J.; Walsh, C.J. Stormwater Management in a Water Sensitive City: Blueprint 2013; Cooperative Research Centre for Water Sensitive Cities: Clayton, Melbourne, VIC, Australia, 2013.

101. Polyakov, M.; Iftekhar, S.; Zhang, F.; Fogarty, J. The Amenity Value of Water Sensitive Urban Infrastructure: A Case Study on Rain Gardens. In Proceedings of the 59th Annual Conference of the Australian Agricultural and Resource Economics Society, Rotorua, NZ, USA, 10-13 February 2015.

102. Du Toit, M.J.; Cilliers, S.S.; Dallimer, M.; Goddard, M.; Guenat, S.; Cornelius, S.F. Urban Green Infrastructure and Ecosystem Services in Sub-Saharan Africa. Landsc. Urban Plan. 2018, 180, 249-261. [CrossRef]

103. Haruna, A.I.; Oppong, R.A.; Marful, A.B. Exploring Eco-Aesthetics for Urban Green Infrastructure Development and Building Resilient Cities: A Theoretical Overview. Cogent Soc. Sci. 2018, 4, 1478492. [CrossRef]

104. Boelee, E.; Janse, J.; Le Gal, A.; Kok, M.; Alkemade, R.; Ligtvoet, W. Overcoming Water Challenges through Nature-Based Solutions. Water Policy 2017, 19, 820-836. [CrossRef]

105. Wendling, L.A.; Huovila, A.; zu Castell-Rüdenhausen, M.; Hukkalainen, M.; Airaksinen, M. Benchmarking Nature-Based Solution and Smart City Assessment Schemes Against the Sustainable Development Goal Indicator Framework. Front. Environ. Sci. 2018, 6, 69. [CrossRef]

106. Ahern, J.; Cilliers, S.; Niemelä, J. The Concept of Ecosystem Services in Adaptive Urban Planning and Design: A Framework for Supporting Innovation. Landsc. Urban Plan. 2014, 125, 254-259. [CrossRef]

107. Hansen, R.; Pauleit, S. From Multifunctionality to Multiple Ecosystem Services? A Conceptual Framework for Multifunctionality in Green Infrastructure Planning for Urban Areas. AMBIO 2014, 43, 516-529. [CrossRef]

108. Bush, J.; Doyon, A. Building Urban Resilience with Nature-Based Solutions: How Can Urban Planning Contribute? Cities 2019, 95, 102483. [CrossRef]

109. Adger, W.N.; Safra de Campos, R.; Siddiqui, T.; Szaboova, L. Commentary: Inequality, Precarity and Sustainable Ecosystems as Elements of Urban Resilience. Urban Stud. 2020, 57, 1588-1595. [CrossRef] 
110. Hansen, T.; Coenen, L. The Geography of Sustainability Transitions: Review, Synthesis and Reflections on an Emergent Research Field. Environ. Innov. Soc. Transit. 2015, 17, 92-109. [CrossRef]

111. Kourdounouli, C.; Jonsson, A.M. Urban Ecosystem Conditions and Ecosystem Services-A Comparison between Large Urban Zones and City Cores in the EU. J. Environ. Plan. Manag. 2020, 63, 798-817. [CrossRef]

112. Zhang, S.N.; Ramirez, F.M. Assessing and Mapping Ecosystem Services to Support Urban Green Infrastructure: The Case of Barcelona, Spain. Cities 2019, 92, 59-70. [CrossRef]

113. Abdalla, H.; Rahmat-Ullah, Z.; Abdallah, M.; Alsmadi, S.; Elashwah, N. Eco-Efficiency Analysis of Integrated Grey and Black Water Management Systems. Resour. Conserv. Recycl. 2021, 172, 105681. [CrossRef]

114. Mercedes Garcia, A.V.; López-Jiménez, P.A.; Sánchez-Romero, F.-J.; Pérez-Sánchez, M. Objectives, Keys and Results in the Water Networks to Reach the Sustainable Development Goals. Water 2021, 13, 1268. [CrossRef]

115. Masi, F.; Rizzo, A.; Regelsberger, M. The Role of Constructed Wetlands in a New Circular Economy, Resource Oriented, and Ecosystem Services Paradigm. J. Environ. Manag. 2018, 216, 275-284. [CrossRef] [PubMed]

116. Cetrulo, T.B.; Marques, R.; Malheiros, T.; Cetrulo, N.M. Monitoring Inequality in Water Access: Challenges for the 2030 Agenda for Sustainable Development. Sci. Total Environ. 2020, 727, 138746. [CrossRef] [PubMed]

117. Olsson, E.G.A. Urban Food Systems as Vehicles for Sustainability Transitions. Bull. Geogr. Socio-Econ. Ser. 2018, 40, 133-144. [CrossRef]

118. Pascual, U.; Balvanera, P.; Díaz, S.; Pataki, G.; Roth, E.; Stenseke, M.; Watson, R.T.; Dessane, E.B.; Islar, M.; Kelemen, E. Valuing Nature's Contributions to People: The IPBES Approach. Curr. Opin. Environ. Sustain. 2017, 26, 7-16. [CrossRef]

119. Zinkernagel, R.; Evans, J.; Neij, L. Applying the SDGs to Cities: Business as Usual or a New Dawn? Sustainability 2018, $10,3201$. [CrossRef]

120. GANSW. Greener Places: Establishing an Urban Green Infrastructure Policy for New South Wales; GANSW: Sydney, NSW, Australia, 2017.

121. Kremer, P.; Hamstead, Z.A.; McPhearson, T. The Value of Urban Ecosystem Services in New York City: A Spatially Explicit Multicriteria Analysis of Landscape Scale Valuation Scenarios. Environ. Sci. Policy 2016, 62, 57-68. [CrossRef]

122. Department of Environmental Protection New York City Green Infrastructure. Available online: https://www1.nyc.gov/site/ dep/water/green-infrastructure.page (accessed on 9 December 2021).

123. Lin, Z. Ecological Urbanism in East Asia: A Comparative Assessment of Two Eco-Cities in Japan and China. Landsc. Urban Plan. 2018, 179, 90-102. [CrossRef]

124. Miao, B.; Lang, G. A Tale of Two Eco-Cities: Experimentation under Hierarchy in Shanghai and Tianjin. Urban Policy Res. 2015, 33, 247-263. [CrossRef]

125. Chang, I.-C.C.; Sheppard, E. China's Eco-Cities as Variegated1 Urban Sustainability: Dongtan Eco-City and Chongming EcoIsland. J. Urban Technol. 2013, 20, 57-75. [CrossRef]

126. Friess, D.A. Singapore as a Long-Term Case Study for Tropical Urban Ecosystem Services. Urban Ecosyst. 2017, $20,277-291$. [CrossRef]

127. Russo, A.; Cirella, G.T. Urban Ecosystem Services: New Findings for Landscape Architects, Urban Planners, and Policymakers. Land 2021, 10, 88. [CrossRef]

128. Secretariat of the Convention on Biological Diversity. Cities and Biodiversity Outlook: Action and Policy: A Global Assessment of the Links between Urbanization, Biodiversity, and Ecosystem Services; Secretariat of the Convention on Biological Diversity: Montreal, QC, Canada, 2000; ISBN 978-92-9225-432-2.

129. Xie, L.; Bulkeley, H. Nature-Based Solutions for Urban Biodiversity Governance. Environ. Sci. Policy 2020, 110, 77-87. [CrossRef]

130. Frost, P. Intergovernmental Bodies and the Greening of Cities: Roles of UN Bodies and International Conventions. In The Routledge Handbook of Urban Ecology; Routledge: Abingdon, UK; New York, NY, USA, 2020; pp. 897-906.

131. Lafortune, G.; Fuller, G.; Schmidt-Traub, G.; Kroll, C. How Is Progress towards the Sustainable Development Goals Measured? Comparing Four Approaches for the EU. Sustainability 2020, 12, 7675. [CrossRef]

132. Lucchitta, B.; Croci, E. An Evaluation Framework to Assess Multiple Benefits of NBS: Innovative Approaches and KPIs. Nat.-Based Solut. More Sustain. Cities Framew. Approach Plan. Eval. 2021, 153, 153.

133. Thomas, R.; Hsu, A.; Weinfurter, A. Sustainable and Inclusive-Evaluating Urban Sustainability Indicators' Suitability for Measuring Progress towards SDG-11. Environ. Plan. B Urban Anal. City Sci. 2021, 48, 2346-2362. [CrossRef]

134. Hawken, S.; Han, H.; Pettit, C. Introduction: Open Data and the Generation of Urban Value. In Open Cities I Open Data: Collaborative Cities in the Information Era; Hawken, S., Han, H., Pettit, C., Eds.; Palgrave Macmillan: Singapore, 2020; pp. 1-25. ISBN 9789811366055.

135. Hawken, S.; Han, H.; Pettit, C. Open Cities I Open Data: Collaborative Cities in the Information Era; Palgrave Macmillan: Singapore, 2020; ISBN 9789811366048.

136. Khoshkar, S.; Hammer, M.; Borgström, S.; Dinnétz, P.; Balfors, B. Moving from Vision to Action-Integrating Ecosystem Services in the Swedish Local Planning Context. Land Use Policy 2020, 97, 104791. [CrossRef]

137. Khoshkar, S.; Hammer, M.; Borgström, S.; Balfors, B. Ways Forward for Advancing Ecosystem Services in Municipal PlanningExperiences from Stockholm County. Land 2020, 9, 296. [CrossRef]

138. Enssle, F.; Kabisch, N. Urban Green Spaces for the Social Interaction, Health and Well-Being of Older People-An Integrated View of Urban Ecosystem Services and Socio-Environmental Justice. Environ. Sci. Policy 2020, 109, 36-44. [CrossRef] 
139. Bai, X.M.; Surveyer, A.; Elmqvist, T.; Gatzweiler, F.W.; Guneralp, B.; Parnell, S.; Prieur-Richard, A.H.; Shrivastava, P.; Siri, J.G.; Stafford-Smith, M.; et al. Defining and Advancing a Systems Approach for Sustainable Cities. Curr. Opin. Environ. Sustain. 2016, 23, 69-78. [CrossRef]

140. Childers, D.L.; Pickett, S.T.A.; Grove, J.M.; Ogden, L.; Whitmer, A. Advancing Urban Sustainability Theory and Action: Challenges and Opportunities. Landsc. Urban Plan. 2014, 125, 320-328. [CrossRef]

141. Evans, T.L. Transdisciplinary Collaborations for Sustainability Education: Institutional and Intragroup Challenges and Opportunities. Policy Futur. Educ. 2015, 13, 70-96. [CrossRef]

142. Bina, O.; Balula, L.; Varanda, M.; Fokdal, J. Urban Studies and the Challenge of Embedding Sustainability: A Review of International Master Programmes. J. Clean. Prod. 2016, 137, 330-346. [CrossRef]

143. Woodruff, S.C.; BenDor, T.K. Ecosystem Services in Urban Planning: Comparative Paradigms and Guidelines for High Quality Plans. Landsc. Urban Plan. 2016, 152, 90-100. [CrossRef]

144. Cross, N. Designerly Ways of Knowing: Design Discipline Versus Design Science. Des. Issues 2001, 17, 49-55. [CrossRef]

145. Pohl, C.; Krütli, P.; Stauffacher, M. Ten Reflective Steps for Rendering Research Societally Relevant. GAIA-Ecol. Perspect. Sci. Soc. 2017, 26, 43-51. [CrossRef]

146. O’Rourke, M.; Crowley, S.; Laursen, B.; Robinson, B.; Vasko, S.E. Disciplinary Diversity in Teams: Integrative Approaches from Unidisciplinarity to Transdisciplinarity. In Strategies for Team Science Success; Springer: Berlin/Heidelberg, Germany, 2019; pp. 21-46.

147. Klein, J.T. Sustainability and Collaboration: Crossdisciplinary and Cross-Sector Horizons. Sustainability 2020, 12, 1515. [CrossRef]

148. United Nations World Commission on Environment and Development. Our Common Future: The World Commission on Environment and Development; Oxford University Press: Suffolk, UK, 1987; ISBN 978-0-19-282080-8.

149. Mann, C.; Garcia-Martin, M.; Raymond, C.M.; Shaw, B.J.; Plieninger, T. The Potential for Integrated Landscape Management to Fulfil Europe's Commitments to the Sustainable Development Goals. Landsc. Urban Plan. 2018, 177, 75-82. [CrossRef]

150. Ricciardelli, A.; Manfredi, F.; Antonicelli, M. Impacts for Implementing SDGs: Sustainable Collaborative Communities after Disasters. The City of Macerata at the Aftermath of the Earthquake. Corp. Gov.-Int. J. Bus. Soc. 2018, 18, 594-623. [CrossRef]

151. Albert, C.; Schröter, B.; Haase, D.; Brillinger, M.; Henze, J.; Herrmann, S.; Gottwald, S.; Guerrero, P.; Nicolas, C.; Matzdorf, B. Addressing Societal Challenges through Nature-Based Solutions: How Can Landscape Planning and Governance Research Contribute? Landsc. Urban Plan. 2019, 182, 12-21. [CrossRef]

152. Kirby, A. Transdisciplinarity and Sustainability Science: A Response to Sakao and Brambila-Macias in the Context of Sustainable Cities Research. J. Clean. Prod. 2019, 210, 238-245. [CrossRef]

153. Wamsler, C. Stakeholder Involvement in Strategic Adaptation Planning: Transdisciplinarity and Co-Production at Stake? Environ. Sci. Policy 2017, 75, 148-157. [CrossRef]

154. Bernstein, J.H. Transdisciplinarity: A Review of Its Origins, Development, and Current Issues. J. Res. Pract. 2015, 11, 1-20.

155. Wickson, F.; Carew, A.L. Quality Criteria and Indicators for Responsible Research and Innovation: Learning from Transdisciplinarity. J. Responsible Innov. 2014, 1, 254-273. [CrossRef]

156. Norris, P.E.; O'Rourke, M.; Mayer, A.S.; Halvorsen, K.E. Managing the Wicked Problem of Transdisciplinary Team Formation in Socio-Ecological Systems. Landsc. Urban Plan. 2016, 154, 115-122. [CrossRef]

157. Hoffmann, S.; Thompson Klein, J.; Pohl, C. Linking Transdisciplinary Research Projects with Science and Practice at Large: Introducing Insights from Knowledge Utilization. Environ. Sci. Policy 2019, 102, 36-42. [CrossRef]

158. Lang, D.J.; Wiek, A.; Bergmann, M.; Stauffacher, M.; Martens, P.; Moll, P.; Swilling, M.; Thomas, C.J. Transdisciplinary Research in Sustainability Science: Practice, Principles, and Challenges. Sustain. Sci. 2012, 7, 25-43. [CrossRef]

159. Mulligan, M.; van Soesbergen, A.; Hole, D.G.; Brooks, T.M.; Burke, S.; Hutton, J. Mapping Nature's Contribution to SDG 6 and Implications for Other SDGs at Policy Relevant Scales. Remote Sens. Environ. 2020, 239, 111671. [CrossRef]

160. Pohl, C.; Truffer, B.; Hirsch Hadorn, G. Addressing Wicked Problems through Transdisciplinary Research. Oxf. Handb. Interdiscip. 2017, 319-331. [CrossRef] 